\title{
LA ESPADA DE PROTOCOLO DEL SULTÁN NAZARÍ MUHAMMAD V
}

\author{
POR \\ VIRGILIO MARTÍNEZ ENAMORADO
}

\begin{abstract}
RESUMEN - ABSTRACT
Este artículo estudia una hoja de espada nazarí atribuida al sultán Muhammad V. El estudio se centra en sus inscripciones, sus fuentes y cronología, así como en su relación con otras espadas nazaríes.
\end{abstract}

This article studies a nasri sword blade attributed to the sultan from Granada Muhammad V. The study is focus in its inscriptions, sources and chronology, as well as its relation to other nasri swords.

\section{PALABRAS CLAVE - KEY WORDS}

Armas blancas, espadas, Al- Andalus, Granada, Muhammad V.

White arms, swords, epigraphy, Al-Andalus, Granada. Muhammad V.

El hallazgo de piezas artísticas andalusíes contenidas en colecciones privadas se repitió con cierta insistencia a lo largo del siglo XIX. En aquella centuria los anticuarios desplegaron una incesante labor de la que se obtuvo como resultado el conocimiento de un buen número de objetos de incalculable valor artístico, conocidos desde entonces a partir de la bibliografía. Es cierto que la búsqueda se centró en las prestigiosas evidencias de la arqueología romana, revestidas de un halo de buena reputación por lo que suponían de recuperación del legado clásico, el precedente más glorioso e imitable en la memoria europeo-occidental. Por el contrario, a los objetos andalusíes no se les prestó tanta atención. Es verdad que a muchas de aquellas joyas se les perdió la pista. Otras tantas se integraron, andando el tiempo, en colecciones públicas, museos que todavía las albergan.

Por razones obvias, a lo largo del siglo XX, tales encuentros se han ido produciendo más esporádicamente $\mathrm{y}$, de hecho, en su segunda mitad los hallazgos pueden ser calificados de esporádicos. Lo que resulta a todas luces excepcional es el descubrimiento en los años iniciales del siglo XXI de un objeto de la valía histórica y artística como el que vamos a presentar a la opinión pública con esta breve contribución.

La espada se integra en la colección privada de arte musulmán al-Furusiyya. Esta primera interpretación del arma en cuestión, con todo su programa decorativo que incluye sendas inscripciones en letra cursiva árabe en cada uno de los lados, nos permite llegar a la conclusión de que se trata de la espada de protocolo de Muhammad ibn Yūsuf, el gran sultán nazarí de laqab al-Ganī bi-llāh, conocido históricamente como Muhammad V, por las razones que a continuación se expondrán. 


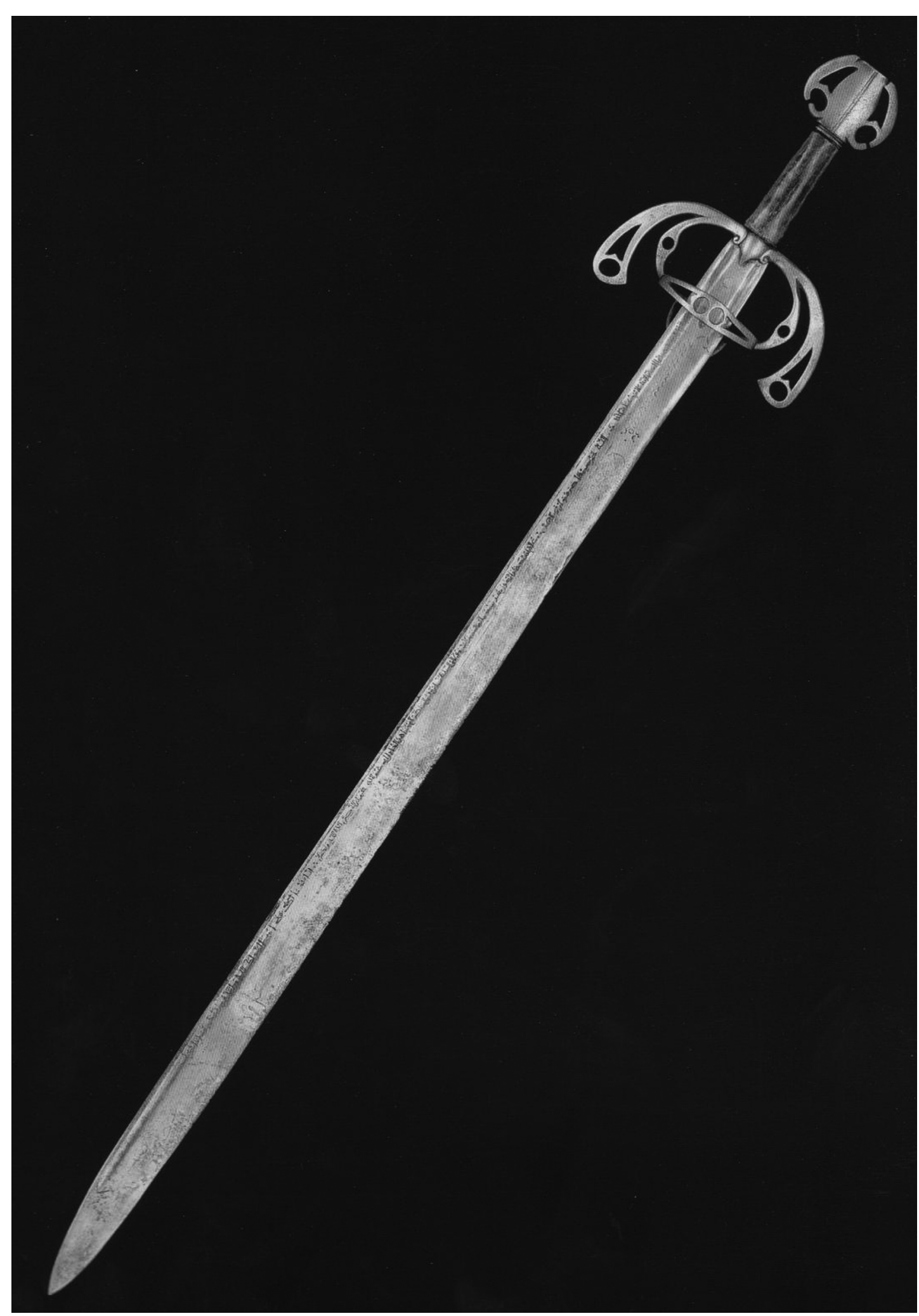

Fig. 1. Espada de Muhammad V. Vista general. 


\section{DESCRIPCIÓN DE LA ESPADA.}

Se trata de una hoja de espada nazarí, de un filo, de $80,5 \mathrm{~cm}$. de longitud por $3,4 \mathrm{~cm}$. de anchura. Su empuñadura ofrece las siguientes medidas: $6 \mathrm{~cm}$. de largo por $8,5 \mathrm{~cm}$. de ancho, mientras que el pomo superior alcanza $6,5 \mathrm{~cm}$. de anchura máxima.

Un elemento que llama la atención en esta pieza es la empuñadura, moderna, que evoca un modelo español de mediados del siglo XVI. Es seguro que el extraordinario valor de la empuñadura original llevaría a su poseedor a reemplazarla por otro elemento menos meritorio. Lamentablemente, nada sabemos sobre la empuñadura primigenia, aunque entendemos que morfológicamente debía ser similar al llamado estoque asociado a Boabdil del Museo del Ejército de Madrid ${ }^{1}$.

La hoja, que está completa, es de doble filo con canal en el tercio superior, por debajo de la inscripción.

\section{LAS INSCRIPCIONES ÁRABES. ANÁLISIS ESTILÍSTICO Y TEXTUAL.}

Las inscripciones árabes en una elegante escritura cursiva plenamente anotada que se desarrolla sobre ambas caras de su hoja son indudablemente lo más señalado de la pieza por la información histórica que aportan, de primerísima magnitud. Además de la inscripción de carácter, si se quiere «fundacional», que pasaremos a analizar más tarde, se observan otras leyendas, símbolos y signos que se repiten de manera muy similar en ambas caras.

Entre las leyendas contamos con dos cuños. Uno, más destacado parece ser la marca del artesano inscrita en un círculo, presumiblemente un tal Fath (فتخح), situado en la parte superior de la hoja que porta la inscripción A. Sin embargo, puede leerse el trilítero f.l. $\hat{y} / f . l . h / f . l . j$. ., todas ellas raíces con distintos significados en árabe, coincidiendo en el de «hendir». Más abajo, en ambos lados un buen número de signos, presentes en otras armas de este estilo y cronología $^{2}$, que incluyen: 40 crecientes, generalmente emparejados, otros aislados; puntos, en la parte inferior de la serie de signos; semicírculo, en esa misma área; líneas coincidentes formando una morfología en «V»; línea que subraya la mayor parte de los crecientes. Por debajo, un desdibujado escudo de la banda granadino, en el que se puede leer el inicio del lema de los nazaríes,

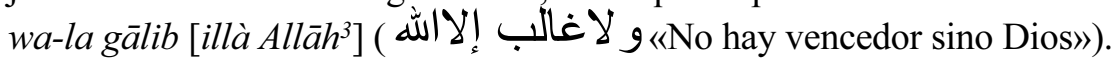

En la otra cara, en la parte final de la inscripción, por debajo de la misma, se aprecia asimismo el escudo de la banda, aún más desdibujado. Finalmente, destacamos el hecho de que por encima de la inscripción A aparece lo que puede ser una marca de propiedad escrita en caracteres castellanos, por ahora indescifrables.

Estamos antes dos inscripciones realizadas sobre ambos lados de la hoja de la espada en dos momentos históricos distintos. La cronología de ambas leyendas, una establecida en el texto y la otra inducida, difiere en unos veinte años. Además, en el estilo caligráfico de uno y

1 Sobre la posibilidad de que la empuñadura de la espada de Boabdil se corresponda con la hoja del arma de Muhammad V, véase más adelante.

2 Por ejemplo, en una espada y vaina nazarí custodiada en el Museo del Ejército de Madrid y que, junto con la espada de Boabdil, forma parte de la entrega que el marqués de Villaseca realizó a dicha institución; $c f r$. Soler del Campo, 1992a: 282. Sobre esta arma, $c f r$. más adelante.

3 Estamos necesitados de un estudio sobre este mote identificativo de la dinastía, tan abrumadoramente presente en casi todas las manifestaciones artísticas nazaríes como lema dinástico. Por lo que respecta al escudo de la banda, parece clara su relación con la heráldica castellana. Según Pavón Maldonado (1970; 1972), se trataría de una concesión de la orden de la banda por parte de Pedro I de Castilla a Muhammad V, quien introduciría ciertas modificaciones, como son la gāliba y la eliminación de los leones castellanos; se fecharía en el segundo reinado del sultán nazarí. Sin embargo, Fernández Puertas (1977) entiende que se trata de un emblema anterior a Muhamamad V e incluso a su padre Yūsuf I. 


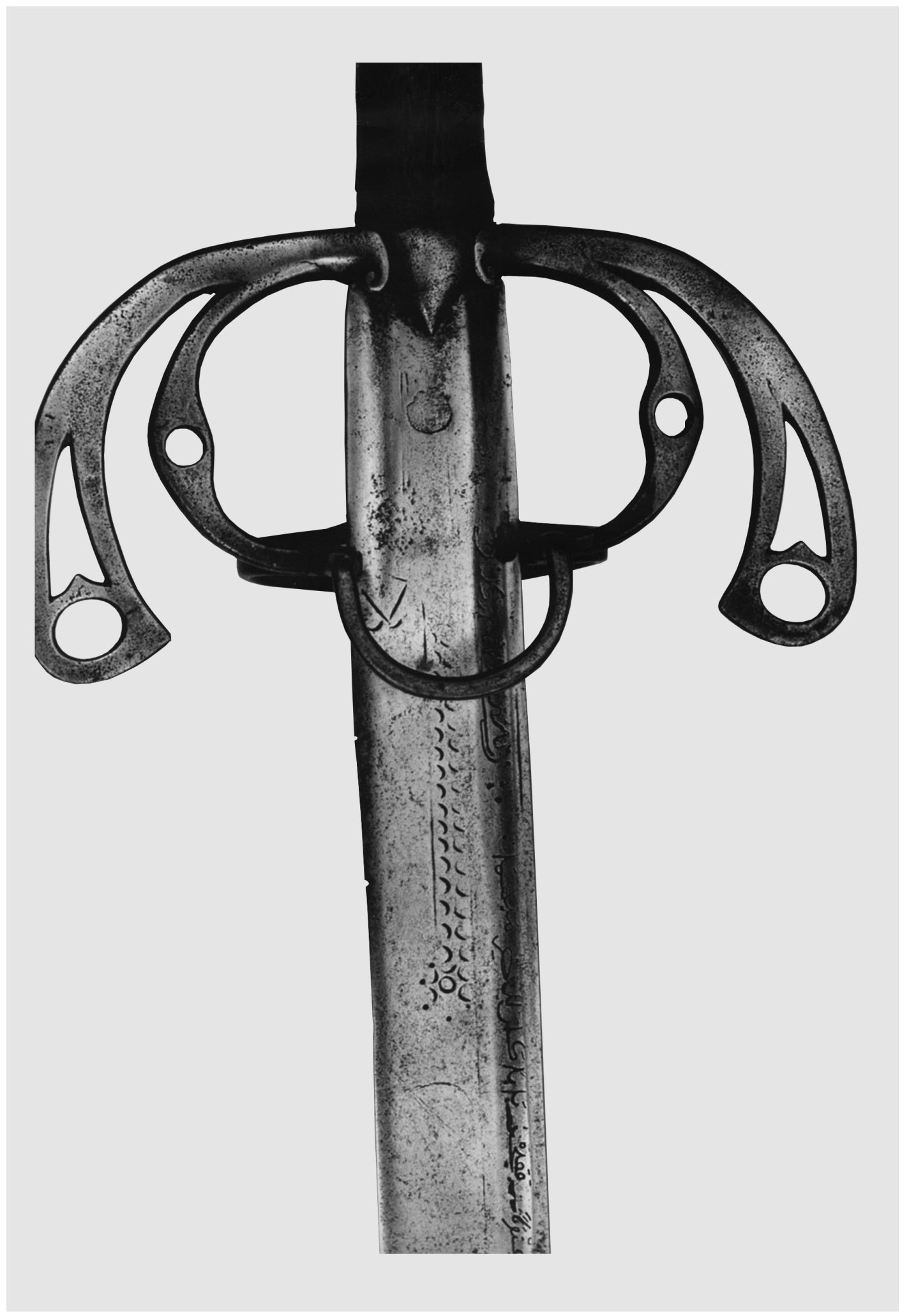

Fig. 2. Espada de Muhammad V. Cara A. Detalle. 


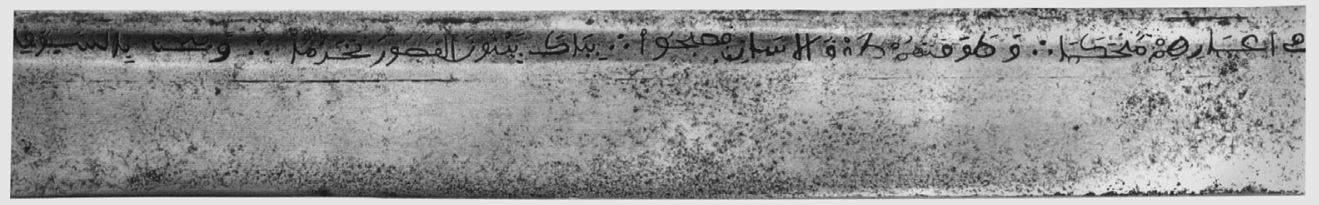

Fig. 3. Espada de Muḥammad V. Cara A. Detalle.

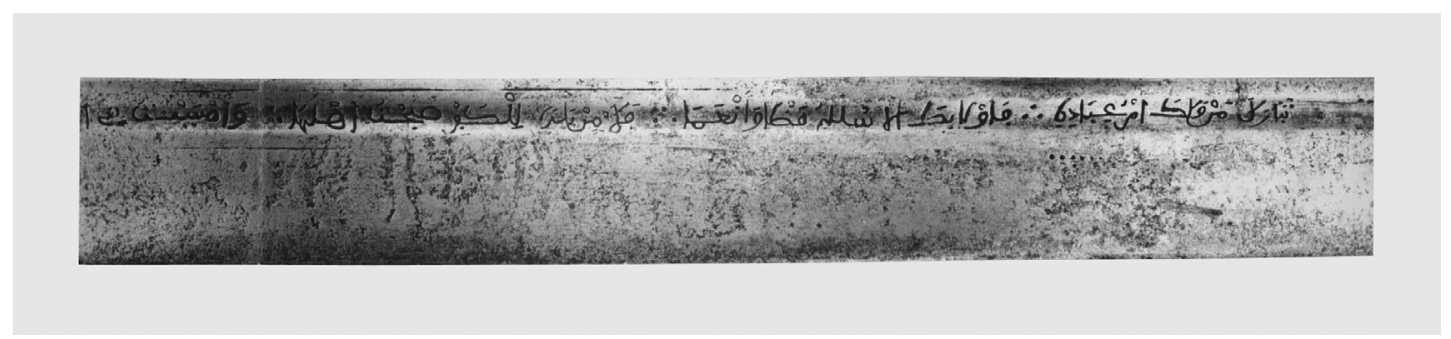

Fig. 4. Espada de Muḥammad V. Cara A. Detalle.

otro lado se observan nítidas diferencias. Ambos textos aparecen separados internamente mediante la inclusión de tres puntos, uno encima de lo dos restantes, a la manera de un pequeño triángulo, lo que es especialmente significativo en el caso del poema de la inscripción B. En la siguiente traducción tal hecho se destaca mediante el signo //. También se observa en ambas caras una línea inferior que delimita los epígrafes, separando la inscripción del campo de la hoja, donde se desarrollan los signos (heráldica, puntos, medias lunas ...) y cuños, anteriormente descritos.

\section{Inscripción A.}

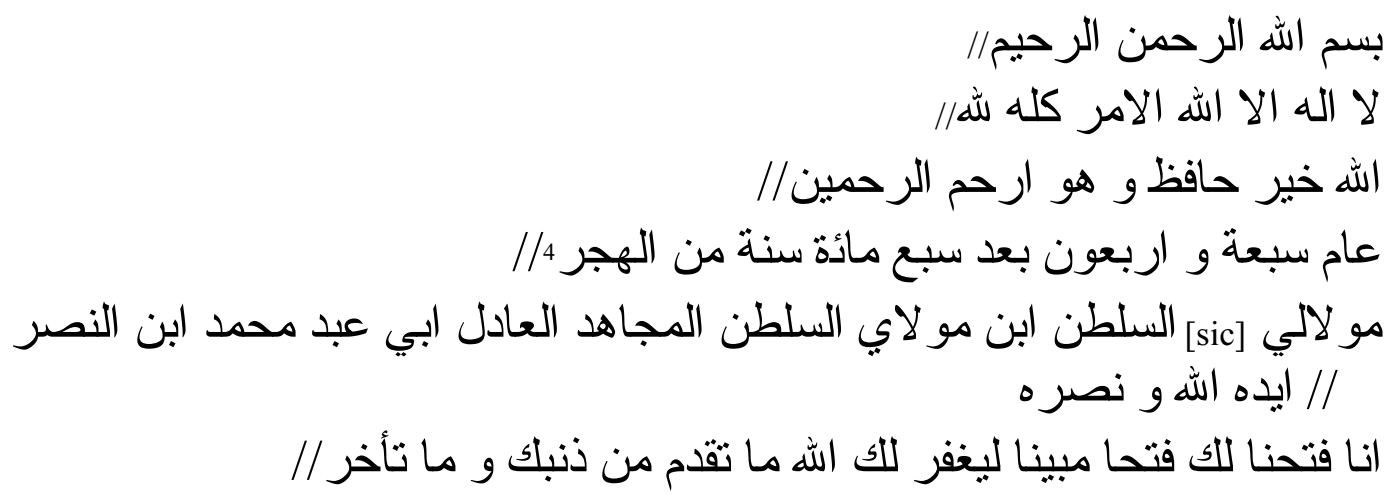

4 La interpretación de la fecha ofrece algunos puntos oscuros que somos, por ahora, incapaces de desvelar. En primer lugar, la doble utilización de los términos 'àm y sana, cuando la presencia de este último se hace innecesaria. Y, en segundo lugar y en relación con la primera advertencia, el empleo de la expresión hiŷr -sic- y no hiŷra, acompañada de una locución que se nos antoja extraña al árabe: sana min al-hiŷr, toda vez que con anterioridad se ha introducido pra la fechación el vocablo 'àm. 


\section{Traducción:}

«En el nombre de Dios el Clemente, el Misericordioso//

No hay más Dios que Dios todo el poder es de Dios $5 / 1$.

Dios es el mejor protector y el más misericordioso de los misericordiosos//

Año setecientos cuarenta y siete (24 de abril 1346/13 de abril 1347 de la Era cristiana) del año de la Hégira, mi señor el sultán ${ }^{6}$, hijo de mi ${ }^{7}$ señor el sultán el combatiente de la fe, el justo, Abū 'Abd Allāh Muhammad Hijo de al-Naṣr-ayúdele Dios y protéjale-//

Te hemos concedido una clara victoria. Para perdonarte Dios tu pecado, pasado y futuro (...) [Corán, 48, aleyas 1 y 2]».

\section{Inscripción B:}

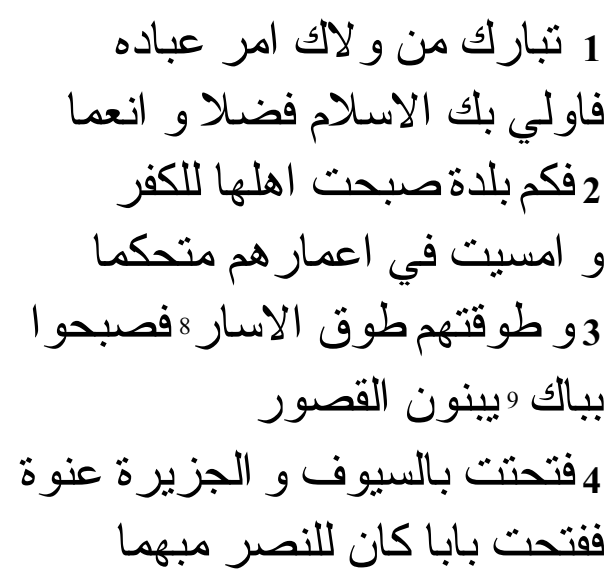

\section{Traducción ${ }^{10}$ :}

" ${ }^{11}$ Bendito Quien te dio mando en sus siervos.//

y en ti gracia y favor al Islam hizo!//

De mañana si a un pueblo vas de infieles, //

eres dueño a la tarde de sus vidas.//

Con dogal de cautivos, tus palacios//te levantan después como albañiles.//

A espadas ${ }^{12}$ y a la fuerza en Algeciras//

entraste abriendo puerta antes cerrada.//

5 Sobre la interpretación de la leyenda al-amru kullu-hu li-llāh, Vega Martín, Peña Martín y Feria García, 2002: 36-173.

6 Extraña en este caso que a Abū 'Abd Allāh Muḥammad ibn Yūsuf, en el año 747 de la Hégira, cuando era príncipe heredero se le considere sultán, hecho para el que, por ahora, no tenemos una explicación convincente.

7 Cabe la posibilidad que la lectura adecuada fuese mawlānā (= nuestro señor).

8 Expresión distinta en la versión de García Gómez. Véase más adelante.

9 Pasaje con pequeña modificación en la versión del Patio de los Arrayanes g. Véase más adelante.

10 Ofrecemos íntegramente la traducción de García Gómez, 1985: 111-114. Véase asimismo la interpretación del poema que efectúa Puerta Vílchez, 2001: 71.

11 Esta fórmula «Bendito quien...» es frecuente en la epigrafía poética de la Alhambra; $c f r$. Puerta Vílchez, 2001: 71.

12 La única variación detectada con respecto al texto emplazado en el Patio de los Arrayanes es el empleo del plural suyüf en lugar del singular sayf. 
El análisis de uno y otro texto nos lleva a las siguientes conclusiones:

Por lo que respecta al análisis textual del epígrafe A, cabe decir que esta inscripción puede ser considerada de carácter «fundacional» en tanto que incluye fechación exacta. El protocolo textual incluye las siguientes fórmulas, bastante conocidas: basmala + tahlīl + expresión «Todo el poder es de Dios» (al-amr kullu-hu li-lāh) + expresión «Dios es el mejor protector y el más misericordioso de los misericordiosos» (Allāh jayr hạfiz wa-huwa arham al-rahminn $)+$ fechación y filiación de la pieza con típicas fórmulas de enaltecimiento de la figura regia («Año setecientos cuarenta y siete del año de la Hégira, mi señor el sultán, hijo de mi señor el sultán el combatiente de la fe, el justo, Abü 'Abd Allāh Muhammad Hijo de al-Nașr-ayúdele Dios y protéjale»= 'àm saba'a wa-arba'ün ba'd saba' mi'a min al-hiŷr mawlātī [sic] al-sulțān ibn mawlāy al-sulțān al-muȳāhid al- 'ādil Abī 'Abd Allāh Muhammad ibn al-Naṣr ayyada-hu Allāh wa-nașara-hu)+ pasaje coránico (48, 1-2). Tanto la fórmula inaugural -basmala- como el tahlīl son pasajes tan utilizados en la escritura monumental y de piezas señeras que no merece la pena detenerse en ellas. Mayor interés ofrece la jaculatoria «Dios es el mejor protector y el más misericordioso de los misericordiosos», empleado en el Patio de los Arrayanes de la Alhambra, bien en su versión breve, como es ésta contenida en la espada, bien en la más larga con el añadido «...Dios el grande, manifestó la verdad» ${ }^{13}$. En alguna de las restantes espadas de la jineta nazaríes se emplea asimismo la misma fórmula ${ }^{14}$

Por su parte, el pasaje coránico con el que finaliza la inscripción A es igualmente un mensaje muy socorrido como fórmula epigráfica en el arte nazarí, por ejemplo, en el Cuarto Real de Santo Domingo (por lo menos, en tres ocasiones) ${ }^{15}$, además de en la Puerta del Vino de la propia Alhambra ${ }^{16}$ y en el patio del Generalife ${ }^{17}$, si bien suele presentarse acompañada de la azora completa.

La fecha proporcionada ${ }^{18}$ (747 de la hégira-1346/7 de la era cristiana) indica que se realizó antes de la asunción del primer gobierno de Muhammad V en la fiesta de al-fițr del año $755 / 19$ de octubre del año $1354^{19}$; ello quedaría refrendado por la titulación que se emplea para referirse al por entonces príncipe heredero (waliy l- 'ahd) Muhammad ibn Yūsuf, exclusivamente su relación de paternidad (kunya) [Abū 'Abd Allāh] y nombre propiamente dicho (ism) [Muhammad]. Se acompaña de un breve nasab que recuerda su vinculación con el epónimo dinástico, Muhammad ibn Nașr [Ibn Nașr ${ }^{20}$ ], fundador de la saga nazarí. Sin embargo, no se incluye el nombre de su padre sino dos de sus epítetos, aplicados en otros textos epigráficos, lo que puede ser entendido como una omisión deliberada, hecho improbable si

13 Puerta Vílchez, 1990: 97-100.

14 Ferrandis no acierta a leer correctamente esta frase en la llamada espada de Boabdil; cfr. Ferrandis Torres, $1943: 160$.

15 Lafuente Alcántara, 2000: 195-197; Pavón Maldonado, 1991. Contamos con una reproducción de una de esas inscripciones coránicas en este espacio en Orihuela Uzal, 1996: fig. 177.

16 Lafuente Alcántara, 2000: 87-88.

17 En un arrocabe de madera junto a la galería; cfr. Lafuente Alcántara, 2000: 187-188; Gómez-Moreno González, 1892: 170; Vílchez Vílchez, 1991: 86.

18 Siguen siendo pertinenentes las aclaraciones relativas de orden cronológico relativas al empleo del término 'àm en lugar de sana para designar el año en cuestión; según Barceló Torres, 1990: 49, en la epigrafía funeraria la utilización de 'ām sólo se extiende, aún sin generalizarse, a partir del siglo XII. Obsérvese el ejemplo de la mqābriyya almorávide algecireña; $c f r$. Martínez Enamorado, 1998b: 84-85. Para la numismática almorávide contamos con el trabajo de Vega Martín y Peña Martín, 2002-2003: 299-306, donde se aborda esa alternancia sana/'ām.

19 Era el hijo primogénito de Abū 1-Hậŷầy Yūsuf [I]. Había nacido la madrugada del 22 de $\hat{y} u m a \overline{d a ̀ ~ d e l ~ a n ̃ o ~ I I ~ d e ~}$ 739/4 de enero de 1339, por lo que en ramaḍ̄an de 747/enero de 1347 era un tierno infante que cumplía únicamente ocho años de edad. Sobre la fecha de su nacimiento, cfr. Vidal Castro, 2000: 133-134.

20 La expresión Ibn Nașr sirve con mucha frecuencia para designar no únicamente a Muhammad V, sino a los distintos sultanes granadinos; en otros poemas de la Alhambra, por ejemplo, en las dos composiciones de las tacas de ingreso a la Sala de la Barca desde el patio de los Arrayanes adjudicados a Ibn al-Ŷayyāb se menciona de esta manera a Muhammad V («[...]Ibn Nașr es en el reino sol hermosísimo que brilla»; «[...] A su grey Dios honor hizo con mi Muley Ibn Nașr»); cfr. García Gómez, 1985: 97-99. Por supuesto es una fórmula muy empleada en la numismática; cfr. Medina Gómez, 1992. 


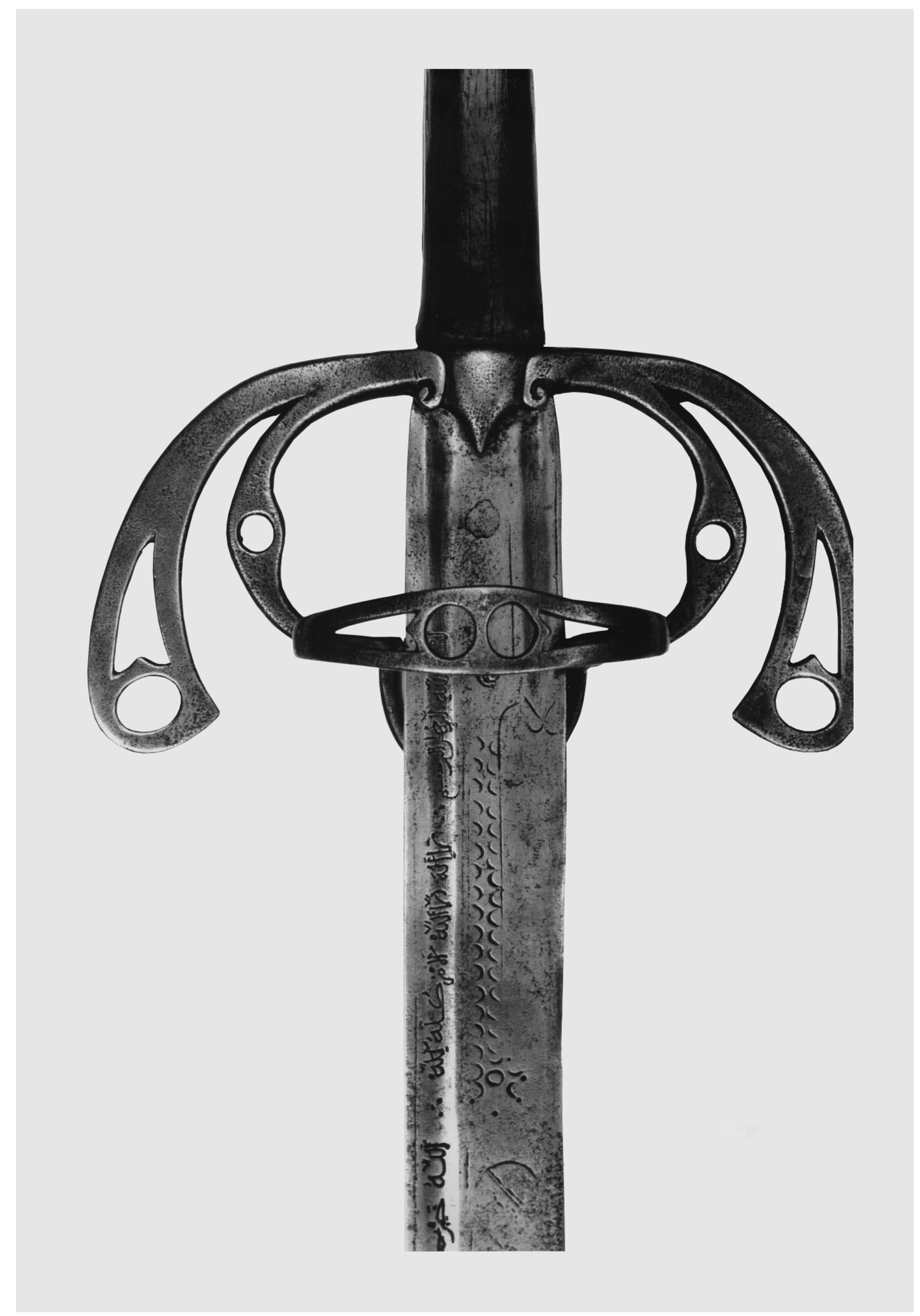

Fig. 5. Espada de Muhammad V. Cara B. Detalle. 


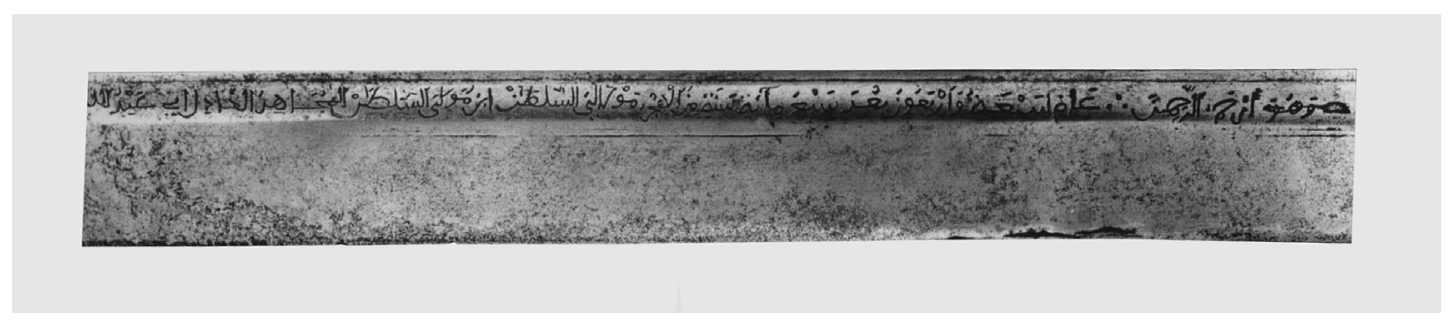

Fig. 6. Espada de Muhammad V. Cara B. Detalle.

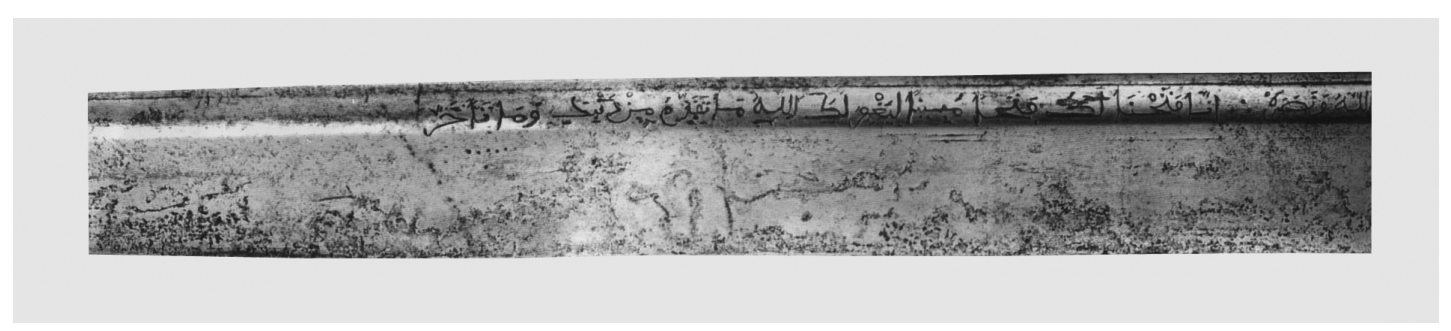

Fig. 7. Espada de Muḥammad V. Cara B. Detalle.

tenemos en consideración la edad del príncipe Muhammad ibn Yūsuf ${ }^{21}$. Más bien, cabe pensar en que la escasez del espacio disponible obligara al epigrafista a acortar ostensiblemente el texto protocolario, omitiendo elementos que, en principio, se considerarían irremplazables, entre ellos el nombre del padre del niño y sultán reinante.

En efecto, entendemos que al-muŷăhid (= el combatiente por la fe) y al- 'ádil (= el justo) se aplican al progenitor del por entonces príncipe Abū 'Abd Allāh Muhammad. Por otro lado, ambos atributos acompañan en ese orden al nombre de Abū 1-Hậŷyâŷ (Yūsuf I) en la inscripción fundacional del māristān de Granada, fechada en 767/136522 y de la Puerta debida a este sultán de la Alhambra ${ }^{23}$, mientras que en la Madrasa Yüsufiyya, mandada edificar por Yūsuf I en el año 750/134924, se repiten ambos epítetos en la retahíla de elogios de Abū l-Walīd Ismā'îl ibn Faraŷ ibn Nașr, si bien en este último caso se introduce el adjetivo alfädil (= el excelente) entre un atributo y otro ${ }^{25}$.

21 No sería el único caso de damnatio memoriae ejecutada por Abū 'Abd Allāh Muhammad (V) -o por poetas y aduladores cortesanos movidos por el deseo de agradar al sultán- hacia su padre Abū 1-Hâŷyâŷ Yūsuf, como ha argumentado con buen criterio García Gómez, 1988: 24-25, quien se refiere a la ausencia del nombre de Yūsuf I en una obra como la Nufâdat al-Ŷirāb de Ibn al-Jațîb, lo que achaca al deseo de su hijo Muhammad (V), por silenciar la obra también la constructiva- de su padre, deseo al que con presteza se acogió el embaucador Ibn al-Jațīb.

22 Por tanto, cuando el soberano llevaba unos 13 años muerto. Sobre esta inscripción del Museo de la Alhambra, Lafuente Alcántara, 2000: 172-175; Gómez-Moreno González, 1892: 132-133; Lévi-Provençal, 1931: 164-166, nº 176.

23 Con fecha del año 749/1348. Es la impropiamente llamada «Puerta de la Justicia». Sobre esta inscripción conservada in situ, Lafuente Alcántara, 2000: 85-86; Almagro Cárdenas, 1879: 3-4; Gaspar Remiro, 1911; Lévi-Provençal, 1931: 156-158, nº 171; Vázquez Ruiz, 1999; Salameh, 2000: fig. 1.

24 Sobre esta inscripción del Museo Arqueológico de Granada, Almagro Cárdenas, 1879: 195-222; de los Ríos, 1883 : 195-196; Gómez-Moreno González, 1892: 308-312; Lévi-Provençal, 1931: 158-160; Eguaras Ibáñez, 1944: 106-108.

25 Todas estas titulaciones están particularmente presentes en los epitafios reales de la rawda de la Alhambra; $c f r$. Lévi-Provençal, 1931: 144 y ss. Tanto al-muŷāhid como al-'ádil son dos epítetos a los que se recurre con asiduidad en la nómina de atributos destinados tanto a los sultanes nazaríes como meriníes, según se ha podido estudiar en la epigrafía oficial de uno y otro aparato burocrático. Sobre algunos ejemplos en la epigrafía oficial meriní, tan similar a la granadina con la que compartía en la práctica las mismas formulaciones, cfr. Aouni, 1991; Martínez Enamorado, 1998a. Sobre el uso del término al-muŷāhid, Martínez Enamorado, 2005. 
Falta por supuesto cualquier alusión al laqab al-Ganī bi-llāh (= el que se da por contento con la ayuda de Dios) adoptado por el sultán Muḥammad ibn Yūsuf (Muhammad V) el 2 de ŷumādà I de 769/25 de diciembre de 1367, después de las campañas militares en la frontera que se iniciaron en Iznájar y acabaron en Úbeda, según testimonio transmitido por Ibn alJațīb en una carta enviada a Ibn Jaldūn, reproducida por éste en su Ta 'rĭ $f^{26}$. La razón es obvia: la inscripción A se fecha en años anteriores a tal asunción del título para-califal por parte de Muhammad ibn Yūsuf, por entonces (747/1346-7) príncipe heredero, mientras que en la B no hay razón para incluir laqab ninguno por tratarse de la célebre qașīda sulțāniyya de Ibn Zamrak $^{27}$, reproducida asimismo en los muros del Patio de los Arrayanes de la Alhambra.

Finlmente, la fórmula que aparece detrás del dueño de la pieza, ayyada-hu Allāh wanașara-hu (= ayúdele Dios y protéjale), es una de las más habituales en el formulario nazarí para referirse a los sultanes, particularmente presente en las monedas de la época ${ }^{28}$.

En la cara B, el célebre poema incluido en el Dīwān de Ibn Zamrak y presente en varias cartelas estrechas entre el zócalo y la pared desnuda de decoración del Patio de los Arrayanes de la Alhambra de Granada se dataría después del año 1369, fecha de la conquista de la ciudad por parte de Muhammad V. Por entonces era arráez del Dīwān al-Inšā' el gran Lisān alDīn Ibn al-Jațī ${ }^{29}$.

Se inscribe este poema en la serie de composiciones panegíricas (qașīdāt sulțāniyya ${ }^{30}$ ) de los aduladores de la corte hacia actos protagonizados por el soberano nazarí, de entre las cuales destaca su labor como conquistador de plazas fuertes. Al respecto, conocemos algún otro ejemplo próximo como es el poema relativo a la conquista de otra plaza fuerte significativa por parte del sultán Yūsuf I, padre de Muhammad V, en este caso el castillo de Carcabuey (hiṣn Karkabūl) en el año 740/1339, qașīda compuesta por Ibn al-Ŷayyāb y contenida en el Dìwān de Ibn al-Jațī ${ }^{31}$. La labor que como poeta panigerista de Muhammad V desempeñó Ibn Zamrak es crucial para comprender la biografía de quien fue uno de los personajes más fascinantes de la convulsa segunda mitad del siglo XIV, como ha sido puesto de relieve por distintos estudiosos ${ }^{32}$.

La excepcionalidad de este poema en el conjunto de composiciones literarias que ocupan los muros de la Alhambra ha sido convenientemente realzada por distintos autores ${ }^{33}$. Su condición de qașida sulțāniyya y no de poema hecho exprofeso para la Alhambra es, a juicio de

26 Ta 'rîf: 128. Medida importante por lo que supone de asunción de un título para-califal, según lo califica García Gómez, 1988: 30-31.

27 O Ibn Zumrak, como argumenta al-Nayfar, 1997: 5, nota 6. Sobre la vocalización del nombre, adscribiéndose a la tesis tradicional, Morales Delgado, 1999.

28 Por ejemplo, Medina Gómez, 1992: 487-529; Robles Fernández y Navarro Santa-Cruz, 2000: 125-135.

29 García Gómez, 1985: 39-41; Rubiera Mata, 1995: 101. Sobre Ibn al-Jațīb, además de la bibliografía citada, puede consultarse una obra recientemente publicada de Molina López, 2001.

30 Véase lo que sobre estos «panegíricos reales» de Ibn Zamrak dice García Gómez, 1975: 100-104.

31 Ibn al-Jațīb, Dīwān, ed. al-Šarīf Qāhir, 244; M. 'A. Makkī, 1984, 15; trad. castellana, Arjona Castro, 1985: 97. Otras qașīda-s conmemorativas de victorias nazaríes, en ciertos casos más deseadas que reales, en Rubiera Mata, 1994: Guadix en 1322 (190-191, XXXIV), Huéscar en 724/1325 (198, CXIX), Guadiana Menor en 741/1340 (198, CXX), Bédmar en 1302 (203, CLXXIX), la Vega de Granada en 719/1319 (204-205, CXCVIII), entre otras. Asimismo recoge esta qașīda sulțāniyya sobre la toma de Carcabuey sin traducirla la misma autora (Rubiera Mata, 1994: 189, XVII).

He aquí la traducción que de la qașìda de la conquista de Carcabuey realizara Arjona Castro:

" ¡Alegría! por la conquista, la aurora de la salvación brilla

iAlegría! Por ello retrocede la noche de la perdición

Una conquista con el auxilio de Él como saludo

su palabra destila la savia del regocijo

Tus espadas conquistaron Carcabuey y ciertamente

con la conquista se demuestra que Dios es el más grande».

32 Blachéré, 1936; García Gómez, 1975; Corriente, 1990; Morales Delgado, 1999; S. Ŷarrār, 1999.

33 García Gómez, 1985: 39-41; Rubiera Mata, 1995: 101. 
M. J. Rubiera, un argumento de primer orden para valorar esta pieza como un elemento insólito en ese libro abierto que es la Alhambra, donde

«el resto de los poemas forman parte de la arquitectura, se componen para el lugar donde están y son obra conjunta del poeta con el alarife y el epigrafista» ${ }^{34}$.

Merece la pena resumir las conclusiones extraídas por A. Fernández Puertas ${ }^{35}$ y desarrolladas por E. García Gómez ${ }^{36}$ del estudio del poema alhambreño. Argumentan ambos estudiosos que Ibn al-Jațīb, en la biografía que dedica a Ibn Zamrak contenida en la $I h \bar{a} t a^{37}$, dice que este poeta recitó al sultán Muhammad V en la noche del mīlād o mawlid (o lo que es lo mismo, la fiesta del nacimiento del profeta que se celebró, como siempre, el día 12 de $r a b{ }^{\top}$ ' I, en este caso del año 772/4 de octubre de 1370) una casida de la que da sus dos primeros versos $^{38}$. En ese momento, según aclara el granadino, el soberano «había terminado las célebres edificaciones en su palacio (bāb) [de la Alhambra]». Es lógico que la misma casida que se recitó en aquella reunión se emplease como adorno poético en las paredes del monumento, toda vez que se trata de un texto anómalo en el conjunto de las composiciones poéticas de la Alhambra, como hemos recogido con anterioridad. Sin embargo, la composición recitada no coincide con la del Patio de los Arrayanes más que en metro y rima, lo que no es obstáculo para que tanto García Gómez como Fernández Puertas se decanten claramente por la posibilidad de que una y otra formen parte del mismo poema. Si a ello añadimos que el polígrafo al-Maqqarī se encarga de aclarar posteriormente que «se trata de una casida larga, con cerca de 90 versos», lo que no fue obstáculo para que el ingenioso Ibn al-Jațīb «se las arreglara, pese a su longitud ${ }^{39}$, parece plausible admitir esa hipótesis de trabajo. De ser así, tendríamos que ese mismo poema del Patio de los Arrayanes se habría recitado publicamente en fecha tan señalada, se habría empleado como mensaje en la espada de protocolo del sultán y, finalmente, figuraría en el Dīwān del poeta áulico Ibn Zamrak. Precisamente, el poeta aclara en su obra que el poema se encontraba inscrito «en el portal del Alcázar de Nuestra Noble Casa (rusima bi-l-naqši fì Burțāli al-qașr min dāri-nā al-karìmati)» ${ }^{40}$, donde Burțāl significa «pórtico» (del Patio de los Arrayanes) y el Alcázar de Nuestra Noble Casa es, evidentemente, la Alhambra. En el lado derecho de ese Pórtico ( $f \grave{l} l$ l-ŷannib al-ayman) incluye Ibn Zamrak nuestro poema con apenas variaciones en relación a la lectura realizada poe E. García Gómez. Antes ha aludido en el Dìwān a la conquista de Algeciras, relacionándola de nuevo con su espada («tu espada», sayfi-ka), aunque el editor confunda esta al-ŶYazira con Mallorca y

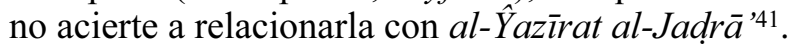

A partir de todos estos ingredientes, García Gómez expone dos hipótesis sobre la fecha de la grabación del poema en los muros del patio de los Arrayanes ${ }^{42}$. O bien tal aconteci-

\footnotetext{
34 Rubiera Mata, 1995: 101.

35 A. Fernández Puertas, 1980, I: 27.

36 García Gómez, 1985: 39-41.

37 Ihạța, II, ed. 'Inān: 307.

38 Los dos primeros versos de la composición son traducidos por García Gómez de la siguiente manera:

«Las huellas del amor vio, dolorido;

penas aprendió de ellas y dolencias

Le despertó el suspiro los recuerdos.

Recorrió en la pasión mil altibajos.»

Para conocer más detalles sobre esta cuestión, García Gómez, 1985: 39-41.

39 Nafh, VII, ed. 'Abbās: 154. No hemos encontrado la cifra de los 90 versos en el texto debido a Ibn al-Jațīb -sí en la nota que remite al Nafh-, a pesar de que García Gómez asegura haber encontrado el detalle en la Ihāta. Por otro lado, este testimonio deja entrever que Ibn al-Jațīb corrigió a su discípulo Ibn Zamrak este poema.

40 Dīwān Ibn Zamrak, ed. Nayfur, 152.

41 Dīwān Ibn Zamrak, ed. Nayfur, 15, nota 1.

42 García Gómez, 1985: 41.
} 
miento se produjo antes de la fuga de Ibn al-Jațīb, con lo que el desaire de ver que un discípulo suyo gozase de tan elevada consideración ante el sultán no haría sino acrecentar el odio entre el lojeño y el gobernante y, a la postre, hubiera servido para acelerar su huida de Granada; o bien, que la grabación en el Patio de los Arrayanes se produjera después del éxodo jațībiano al Magreb, suposición que convence más al arabista español. En cualquier caso, no podemos valorar la incidencia que tuvo la grabación del poema en la espada en este hecho, aunque, como intuye con muy buen criterio García Gómez, es de imaginar que el honor dispensado a Ibn Zamrak por Abū 'Abd Allāh Muḥammad no pasara desapercibido y que creara acusados resquemores en los círculos cortesanos, especialmente en el picajoso Ibn al-Jațīb. La inclusión de esta hermosa poesía en el arma de protocolo del sultán no hace sino confirmar la relevancia que pudo tener este asunto, si bien somos incapaces por ahora de valorar los detalles que nos permitan explicar hasta que punto esto fue así. El poema se completaría con otro verso recogido por Yūsuf III en su obra poética y que rezaría

\section{«Un alcázar Dios te ha dado por el que, ante nuestras miradas, se eleva la luna radiante y plena del Islam» ${ }^{43}$.}

El poema del patio de los Arrayanes consta de 12 versos en țawīl (rima $m \bar{a}$ ) escritos en cartelas alargadas sobre el zócalo rodeando el archiconocido patio alhambreño. No dejamos de preguntarnos si cuando Ibn al-Jațīb describe las composiciones epigráficas de la Alhambra como frases de política (fușūl al-siyāsa) tiene en la mente en concreto el poema de Ibn Zamrak, el único claramente «político» del conjunto de inscripciones de la Alhambra, a no ser que incluya entre este tipo de frases a todas las adulaciones, siempre desmesuradas, destinadas a los sultanes que colman los muros y paredes de la Alhambra, como quiere ver García Gómez ${ }^{44}$. En la espada sólo están presentes los cuatro primeros versos de la composición que se muestra en el recinto de la Alhambra. Cuando Lafuente Alcántara realizó la lectura del poema in $\operatorname{situ}^{45}$, la escritura del mismo sita en la Alhambra se encontraba casi borrada, por lo que hubo de suplir en nota cuatro de los versos (números $5,7,8$ y 10) con la lectura y traducción que realizara Castillo por orden del Concejo o Cabildo granadino en $15644^{46}$.

De la importancia histórica del asunto tratado en el poema apenas si merece la pena llamar la atención por lo destacado del hecho en sí. No obstante, describiremos someramente los acontecimientos. La conquista de la ciudad de Algeciras (al-ŶYazirat al-Jadră') en 26 de $\underline{d} \bar{u} l$ l-hîŷya del año 770/31 de julio de 1369 tuvo una repercusión espectacular, reflejada en las

43 Puerta Vílchez, 2001: 71.

44 García Gómez, 1985: 174-175 entiende que este pasaje contenido en la Nufāọa de Ibn al-Jațīb (III: 275-276) que a continuación reproducimos es la única mención conocida de la abundantísima poesía epigráfica de la Alhambra producida en tiempos nazaríes. El pasaje en cuestión es, según traducción de García Gómez, 1988: 143 que mejora la de 1985, el siguiente: «En todas las paredes [las de la qubba] ondea el mar de los azulejos (bahr al-zulayy), cuyo oleaje represa por encima una faja en la cual se halla grabado un poema que reúne máximas politicas: las letras están recubiertas por panes de oro purísimo y entre ellas se aglutina lapislázuli molido». Ahora bien, sabemos que el poeta está hablando en ese momento de la «alta qubba del trono», o lo que es lo mismo, la Sala de las Dos Hermanas. Sobre el poema de esta dependencia de la Alhambra, cuya autoría corresponde al gran Ibn Zamrak, García Gómez, 1985: 115120 , con descripción de la arquitectura.

45 Esta fue la traducción que efectuó Lafuente Alcántara (2000: 95) de los 4 versos que contiene la espada, básicamente seguida por E. García Gómez:

«Bendito sea el que te concedió el mando de sus servidores, y ensalzó por ti el Islam cumplida y benéficamente.

¡Cuántas veces te acercaste por la mañana a las ciudades de los infieles, y fuiste por la tarde árbitro de la vida de sus habitantes!

Les impusiste el yugo de los cautivos,y amanecieron en tu puerta construyendo los alcázares, como servidores tuyos.

Conquistaste Algeciras por fuerza de armas, y abriste al socorro una puerta que estaba cerrada»

46 Traducciones de las inscripciones de la Alhambra que permanecen todavía inéditas en un manuscrito de la Biblioteca Nacional de Madrid ( $\mathrm{n}^{\circ}$ 7.453); sobre Alonso del Castillo y su labor como epigrafista, Cabanelas Rodríguez, 1976; 1991; Rubiera Mata, 2000: XVII-XVIII. 
crónicas árabes con particular incidencia ${ }^{47}$. La consideración que esta ciudad tenía como «puerta de al-Andalus» ( $b \bar{a} b$ al-Andalus ${ }^{48}$ ) desde la conquista árabo-islámica acrecentó el interés que despertaba su dominio y el de toda la región del Estrecho de Gibraltar, para lo cual compitieron todas las potencias cristianas cristianas peninsulares y los poderes musulmanes nazarí y meriní. Tras la batalla de Salado, que tuvo lugar en 7 de ŷumādà I de 741/30 de octubre de 1340, la plaza se perdió para el Islam. Sin embargo, en 1369, la otrora capital meriní en al-Andalus ${ }^{49}$ fue conquistada por Muhammad $\mathrm{V}$, en una acción que fue cantada por diversos poetas y cronistas ${ }^{50}$, aunque de hecho no fuese más que una acción militar sin excesiva grandeza: en apenas tres días conquistó Muhammad V la plaza, defendida por una exigua guarnición castellana ${ }^{51}$. Así describe Ibn al-Jațīb, responsable de varios de los documentos en lengua árabe más significativos de dicho evento, la conquista de Algeciras en una carta del aparato burocrático granadino recogida en su Rayhạnat al-kuttab:

«Y la más reciente de las ciudades conquistadas ha sido la ciudad de Algeciras, puerta del Islam por donde entró la conquista, y sobre la cual fueron grandes con la palabra de Dios, el favor y la gracia divinos, cuyo gran poderio vino a ser mayor de lo que la imaginación podía representarse y más de lo que podia esperar. Ella ha apretado fuertemente al cuerpo del Islam las vestiduras de la bendición y de la prosperidad» ${ }^{52}$.

Al no estar seguro de que su ejército pudiera preservar la ciudad de los frecuentes ataques cristianos, Muhammad V al-Ganī bi-llāh mandó arrasar por completo Algeciras, convertida desde entonces en un despoblado, situación en la que se mantendrá a lo largo de centurias, pues la ciudad del Estrecho no renacerá como tal hasta el siglo XVIII.

La ubicación de estos panegíricos al sultán es muy diversa. Algunas de estas casidas se escriben exprofeso para adornar determinados objetos muebles, según sabemos por el Dīwān de Ibn al-Ŷayyāb, quien escribió al menos tres de estas composiciones en piezas de la corte: una destinada a un sultán meriní sobre un tapiz facturado en la Alhambra ${ }^{53}$, otra sobre un velo fabricado en la Casa Real destinado a Yūsuf I ${ }^{54}$ y una tercera que se grabaría sobre la diadema de un trono de novia ${ }^{55}$.

Por lo que respecta a su empleo en espadas regias, muy frecuente en el arte islámico desde los primeros tiempos ${ }^{56}$, tenemos distintas constancias que avalan la predilección que algunos sultanes nazaríes tenían por acompañar las armas con qaṣida-s laudatorias hacia su persona. Yūsuf III, por ejemplo, mandó grabar un poema en la vaina de una espada (gamidi sayfin) recogido en su $D \bar{\imath} w \bar{a} n^{57}$. Independientemente de ello, nada sabemos sobre la partici-

47 Ihāța, II, ed. 'Inān: 88-90; Rayhānat al-Kuttab,ed. 'Inān, 203-205; trad. Gaspar Remiro, 1915: 6-8; 'Ibar: trad. de Slane, IV: 380-381; 'Abbādī, 1975: 86; Arié, 1990: 115; Torremocha Silva, 1994: 294-296; Torremocha Silva y Sáez Rodríguez, 2001: 205-208.

48 Como «conquista primera de los musulmanes, puerta de nuestra patria, acceso a la casa del Islam» es calificada por Ibn al-Jațīb, quien emplea adjetivos similares en otras varias ocasiones haciendo alusión a acontecimientos fechados durante el sultanato nazarí; por ejemplo, Ihạța, II, ed. 'Inān: 88; Lamḥa, ed. M. al-Jațīb: 110 y trad. castellana de Casciaro, 120.

49 Sobre la Algeciras meriní, Torremocha Silva et alii, 1999.

50 Véase la descripción que de la conquista hizo Ibn al-Jațīb en Ihāṭa II, ed. 'Inān: 88-90; Ihāta IV, ed. 'Inān: 554558. Sobre este episodio, cfr. el comentario de Abboud Haggar, 1998: 163.

51 Torremocha Silva y Sáez Rodríguez: 2001, 207.

52 Rayhānat al-kuttab, ed. 'Inān: 211; trad. castellana Gaspar Remiro, 1914: 301. Asimismo, con anterioridad Ibn al-Jațīb recoge una carta en la que se describe con todo lujo de detalle la toma de la ciudad de Algeciras, misiva del sultán Muḥammad V al jeque de la Meca que por su longitud no reproducimos en esta ocasión; cfr. Rayhạāat al-kuttab, I, ed. 'Inān: 203-205; trad. Gaspar Remiro, 1915: 6-8.

53 Rubiera Mata, 1994: 198, CXVI.

54 Rubiera Mata, 1994: 202, CLXIV.

55 Rubiera Mata, 1994: 204, CLXXXVII.

56 Zaki, 1957.

57 Dìwān Yūsuf III, ed. Kannūn, 130. 
pación de la Cancillería o Secretaría nazarí (dīwān al-inša $\bar{a}$ ') en estos trabajos especializados, aunque es posible que entrara dentro de sus competencias la preparación y supervisión de estos textos destinados a objetos suntuarios de la realeza ${ }^{58}$

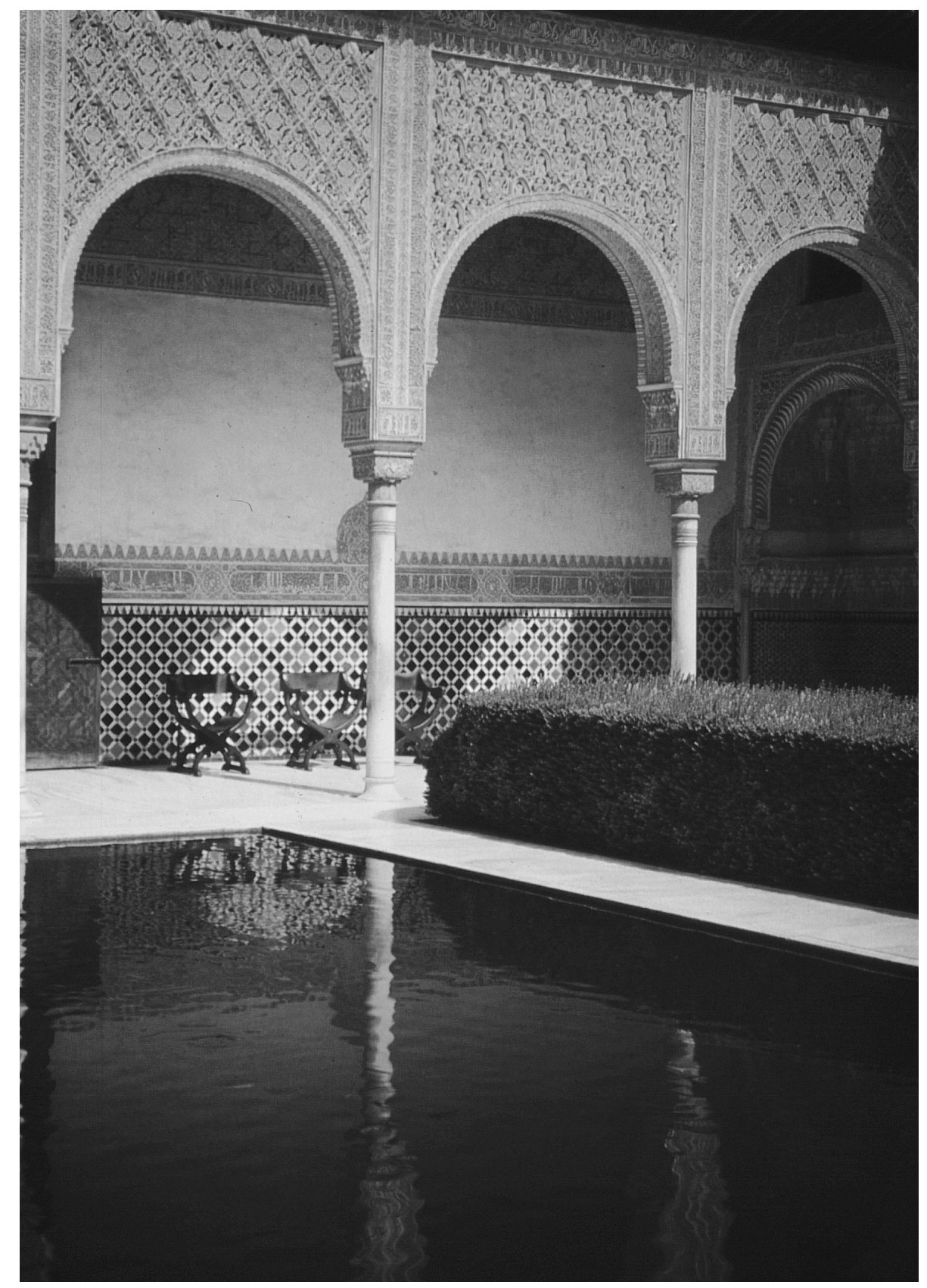

Fig. 8. Patio de los Arrayanes, donde se encuentra el poema de Ibn Zamrak. Alhambra (Granada).

58 Sobre el funcionamiento de la Cancillería nazarí, Viguera Molins, 2000a: 345-351. 


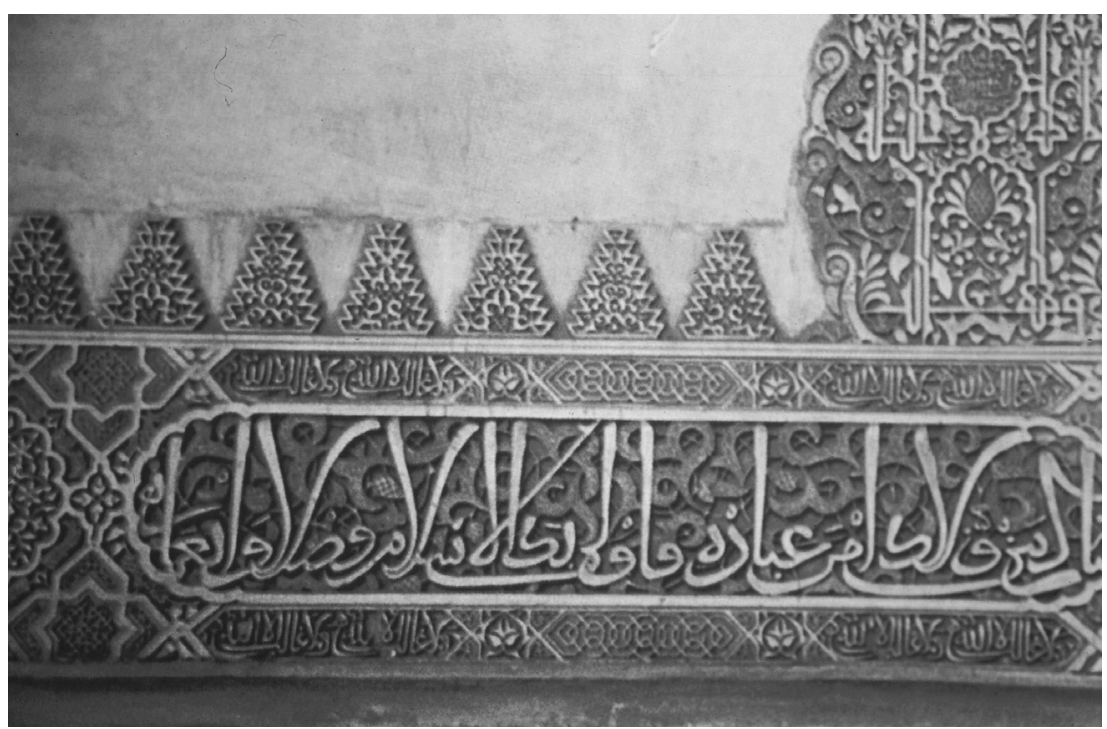

Fig. 9. Fragmento del Poema de Ibn Zamral. Patio de los Arrayanes. Alhambra (Granada).

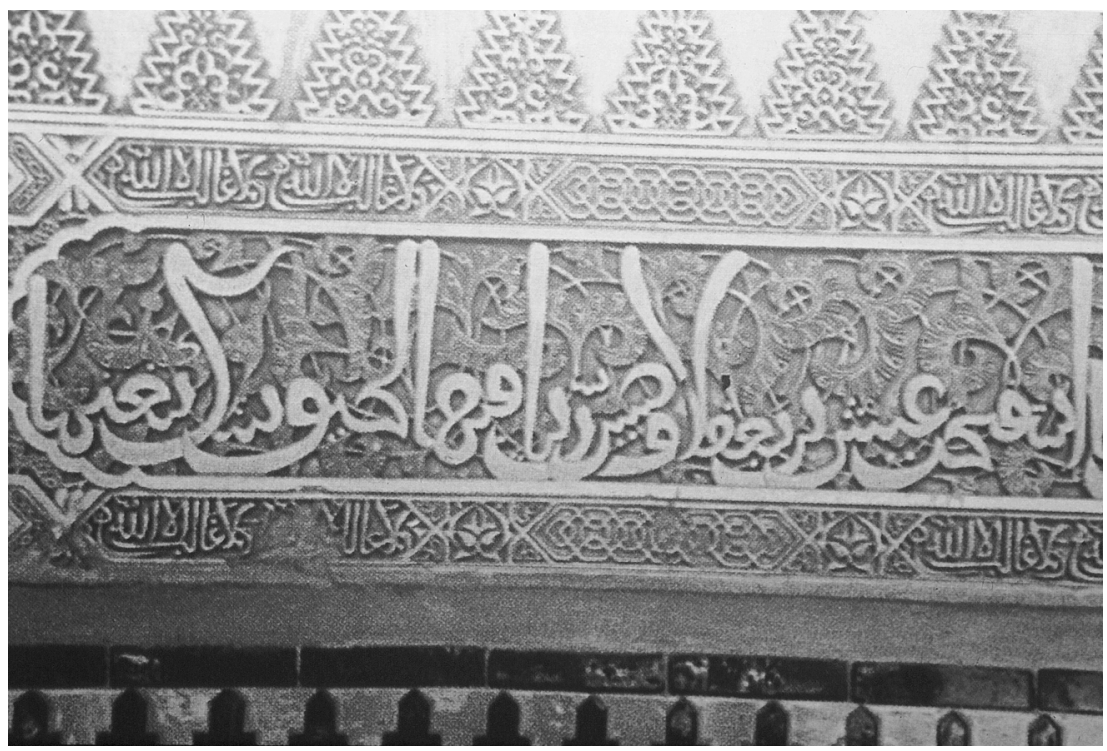

Fig. 10. Fragmento del Poema de Ibn Zamrak. Patio de los Arrayanes. Alhambra (Granada).

Entrando en el análisis formal y estilístico de ambas inscripciones, cabe decir que presentan en ambos casos la anotación secundaria plena, como suele ser habitual en este tipo de inscripciones nazaríes. Se observa una clara diferencia en el tratamiento de la caligrafía entre una y otra cara de la espada: mientras que en la cara A, la letra es mucho más elegante y cuidada, en la B se aprecia una evidente tendencia al descuido. Tanto en uno como en otro caso, la tipología de la letra es la típica caligrafía nazarí, detectándose que la puntuación del $f \bar{a}$ ' y 
del $q \bar{a} f$ se resuelven a la manera magrebí. Los errores existentes no afectan a la lectura integral de la leyenda. Se mantiene la línea del renglón.

En la inscripción A, el único error perceptible es la presentación del término mawlāy bajo la forma mawlālì. Sin embargo, más adelante, sí aparece debidamente escrito, aunque resulte curioso comprobar como el nexo lā se une al grafema posterior. Por lo demás, en esta

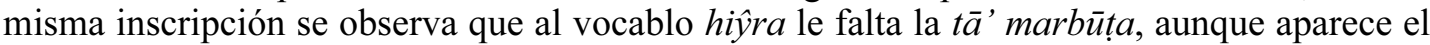
grafema sobre la misma palabra.

En la inscripción B, se observa que la parte inferior de algunos grafemas se han borrado, lo que, sin embargo, no llega a dificultar su lectura. Además, se aprecian dos errores. Por un lado, la pérdida del alif maqșūra en la expresión al-isārà ${ }^{59}$, así como, por otro, la incorrección de la expresión siguiente: fa-șabaḥu bi-bāk en lugar de wa-aṣbaḥu bi-bāabi-ka. Con respecto al texto del Patio de los Arrayanes se da una clara divergencia: el vocablo sayf en singular en la Alhambra y en el Dīwān y en plural en la espada (suyūf).

\section{CONCLUSIONES}

Aunque hay una disparidad cronológica evidente entre las inscripciones de ambos lados de la hoja, esta se entiende si la conectamos con la condición de la pieza, espada de protocolo del gran sultán granadino Muhammad V, condición que poseía con anterioridad a su acceso al trono de acuerdo con la inscripción A. Merced a esa consideración de objeto suntuario, se comprende el añadido posterior del poema de Ibn Zamrak, conmemorativo de la conquista de la importante plaza de Algeciras (inscripción B). Desgraciadamente, falta un elemento de capital relevancia, la empuñadura, sustituida por otra de época moderna. Sin embargo, no debemos llamarnos a engaño sobre la representatividad de la empuñadura como objeto dotado de un especial simbolismo. En el Islam, son conocidas las comparaciones entre las espadas y los seres humanos en el sentido de que al igual que en estos últimos, el valor de la espada no radica en el adorno que acompañe la testa del personaje, sino en el propio individuo. Dicho de otra manera, lo trascendente no está en el turbante con todos sus tocados y aderezos (la empuñadura en la espada) sino en el individuo que lo porta (la hoja). En este caso, este elemento conservado se dota de todo un discurso literario con el que se trata de ensalzar la pieza como contenedor poético de uno de los mejores literatos de la corte, emulando a los muros del gran palacio de la Alhambra. No es de extrañar por ello que este poema tenga mucho que ver con aquella enemistad entre Ibn al-Jațīb e Ibn Zamrak, especialmente intensa por tratarse de maestro y discípulo, conocedores a la perfección, por tanto, de los defectos y virtudes del otro. Precisamente, conocemos el texto por el que Ibn Zamrak es designado jefe de la Secretaría nazarí ( $r a$ 'ìs dīwān al-inšs ${ }^{\prime}$ ), redactado, como no podía ser de otra manera, por su maestro Ibn al-Jațīb y que nos habla de un control por parte del poeta de todos aquellos documentos que emanaran de la administración granadina:

«Este es un noble decreto (zāhir) ... por el cual el emir Fulano [Muhammad V] nombra a Fulano [Ibn Zamrak], y lo traslada de los bancos de aprendizaje y de la enseñanza a los puestos de honor y de la elevación y al rango que sólo reciben los personajes muy relevantes, haciendo de sus cálamos corceles que hagan circular las altas órdenes y las preciosas cartas reales por todos los hipódromos del país ... Le confiere por él primacía y precedencia sobre los [otros secretarios] de su cancillería ... Cuando Dios nos quitó nuestro reino ... fue de los que se señalaron y distinguieron por su lealtad ... lo nombro secretario confidencial y depositario de mis mandatos y prohibiciones, eligiéndolo después de haberlo aprobado» ${ }^{60}$.

59 Señala García Gómez, 1985: 95 que puede tratarse tanto de asāri= cautividad, como de asārà = cautivos. En la versión del Dīwān, ed. Nayfur, 153, al-isāri

60 García Gómez, 1975, 43-44, nota 2; Viguera Molins, 2000a: 349. 
Con la composición literaria de Ibn Zamrak que adorna la espada, se trata de hacer hablar con hermosísimas palabras a pieza tan señera, que era portada por el más alto dignatario del poder granadino, al tiempo que se ensalza la figura real ${ }^{61}$. Señala $\mathrm{R}$. Ward que las piezas en metal del período mameluco, «are dominated by inscriptions which trumphet the social position of their owner so loudly that the vessels seem intended more as vehicles of propaganda than for pleasure and appreciation $\rangle^{62}$, definición que viene muy bien asimismo al caso de la espada de Muhammad V y al de tantos otros objetos regios nazaríes convertidos en obras «políticas» por lo que tienen de indisimulada propaganda en favor del poder real.

Si bien es cierto que la espada como símbolo de poder ha tenido en el Islam un lugar destacado entre la panoplia de objetos destinada a ensalzar a los gobernantes que detentaban la jefatura $^{63}$, a lo largo del período nazarí se observa un incremento de las prácticas destinadas a dotar a estas armas de un mayor protagonismo en las ceremonias, y de ahí la creación de una tipología particular, las espadas de jineta, que puede coexistir, y de hecho así ocurre, con ejemplares cristianos documentados en las fuentes y en algún de colección ${ }^{64}$. Las jinetas se incorporan de pleno como argumento esencial y de primer orden a la imagen parafeudal que el poder nazarí tenía de sí mismo, emparentándose en cierto sentido con comportamientos ajenos al Islam y propios de las sociedades europeo-occidentales coetáneas. La visión que sobre las armas tiene el mundo feudal incluye la personalización de la misma, especialmente las espadas, que puede llegar a contar con un nombre propio ${ }^{65}$, o su sacralización. Igualmente, se vinculan de tal manera a su posesor que termina por identificarse con él ${ }^{66}$. Nada que ver, por tanto, con la genérica adscripción al universo árabe de la espada como objeto que otorga señorío y nobleza realizada, por ejemplo, por Ahnaf ibn Qays: «Los árabes serán árabes mientras continuen vistiendo turbante y portando espada ${ }^{67}$, convertida el arma en seña de identidad de toda una colectividad tan amplia.

En este caso concreto, podemos incluir esta pieza entre los signos de soberanía de los sultanes, aunque no figuren en las fuentes espadas reales granadinas cumpliendo esa función de piezas de protocolo y sí el turbante, la túnica y otros atributos de realeza a los que los emires nazaríes recurrieron para manifestar su soberanía y mostrar ante el mundo la legitimidad de su poder soberano, hecho muy habitual entre los sultanes musulmanes ${ }^{68}$. Es evidente a la luz de los textos que toda esa presentación protocolaria se intensificó de manera desmesurada con Yūsuf I y, particularmente, con Muhammad V. En las crónicas, las armas se incluyen como

61 Lamentablemente, ni una palabra concreta dice Lisān al-Dīn Ibn al-Jațīb en su exposición de la celebración del mawlid de 1362 de la espada de Muhammad V, si no son las alusiones genéricas contenidas en las poesías que se recitaron tras la fiesta en sí: «Tu acero (al-sayf) clavará donde lo empuñes; doquier tenses saeta, El será arquero» (Nufāda III: 283; trad. García Gómez, 1988: 165)»fina lluvia, las dádivas por nube; león fiero, por garras las espadas» (Nufāda III: 284; trad. García Gómez, 1988: 166)

62 Ward, 1993: 95.

63 Sobre ello, Zakī, 1957. Las inscripciones en armas, en general, han sido tratadas someramente por Blair, 1998 : 199-203 y bibliografía allí citada.

64 Como la pequeña espada encontrada en Prado del Rey (Cádiz), custodiada en el Museo Arqueológico de Sevilla; $c f r$. Soler del Campo, 1992a: 282; 1995c: 146, $\mathrm{n}^{\circ} 113$. Este ejemplar, aunque es claramente andalusí, deja ver influencias cristianas. Soler habla de una tipología diferenciada de armas nazaríes, en la que las influencias del armamento cristiano son patentes; de entre las piezas conocidas, esta es, sin duda, la más representativa.

65 Obsérvese en que en la descripción de la espada contenida en un documento del siglo XVII que posteriormente analizaremos se le da nombre inventado a la misma.

66 Recordemos para este último asunto el caso paradigmático de la llamada espada de San Fernando, conservada en la Capilla Real de la Catedral de Sevilla. Sobre esta espada y su sacralización hasta convertirla en auténtica reliquia, Hernández Núñez, 1999: 234-235 y bibliografía allí citada. Con dicha espada se exhibió el Infante por toda la ciudad de Sevilla, según se relata en la Crónica de Juan II de Castilla, 129-131.

67 Ibn Hudayl, Kitāb hilyat al-fursān, trad. Viguera, 179.

68 Sobre ellos, Viguera Molins, 2000a: 332-336. 
uno más de los atributos de realeza, destacándose casos concretos, como el de Ismā'îl I, sultán granadino que, en palabras de Ibn al-Jațīb, «sentía gran placer en procurarse buenas armas (silāh) $\rangle^{69}$, se supone que para ser vistas no sólo por los círculos del poder, sino también por los súbditos, que quedarían admirados ante una exhibición del mulk tan impactante. Igualmente, la posibilidad de que Muhammad V usara el cetro de mando fabricado para su padre ${ }^{70}$ y la potenciación de formas protocolarias de mayor enjundia, entre ellas la utilización de un trono específico (kursī malik), datado en época de al-Ganī bi-llāh ${ }^{71}$, y de la túnica real (jil 'at al-mulk) ${ }^{72}$, ademanes que sirven para la representación mayestática de un poder que quiere ser legítimo y autocomplaciente, son indicios que permiten situar el arma analizada en su adecuado contexto social y político. Es en el segundo reinado de Muhammad V cuando se da una mayor relevancia a toda esta pompa cortesana, lo que explica en buena medida la dotación de la espada como objeto parlante con una composición del más ilustre de sus poetas áulicos.

Meritorio, por tanto, es señalar la presencia anterior del nombre del posesor, en 747/1346-1347 el príncipe Abū 'Abd Allāh Muhammad, heredero al trono que detentaba su padre Abū l-Haŷȳâŷ Yūsuf I, lo que invalida la posibilidad de que la pieza pudiera haberse destinado al mercado. Por el contrario, estos significados objetos de prestigio pasan a formar parte del patrimonio del gobernante bien como regalos hechos al soberano por otros miembros cercanos al círculo del poder ${ }^{73}$, bien como encargos especiales y personales por parte del sultán o príncipe de turno. Estos metales, junto con otras piezas significadas (tapices, banderas, telas, joyas, jarrones de la Alhambra...), se integran en un «patrimonio real» formado a través de varios aportes, según se ha puesto de manifiesto en el caso de la metalistería del período ayyubi ${ }^{74}$. Como parte del «mustajlas mueble», las armas de carácter protocolario se destinaban a ceremonias especiales, y no, al menos en teoría, a acciones de guerra, aunque bien es cierto que si había que utilizarlas en batalla "eran tan eficaces como las más corrientes ${ }^{75}$. A partir de algunos testimonios textuales, se puede conocer los objetos suntuarios que conformaban ese tesoro de la casa real nazarí (jizāna had̄a al-dār lo denomina alMaqqarī), que incluía «espadas (suyūf) de excepcional invención y extraordinaria maravilla, parecidas en tersura a la piel de las mejillas, con [empuñaduras] adornadas de oro puro de tíbar ${ }^{76}$, alusión, sin duda, a las célebres espadas de jineta granadinas.

Si la llamada espada de Boabdil y la espada-estoque ${ }^{77}$ que junto a aquella se dice fueron requisadas al último sultán granadino tras la batalla de Lucena ${ }^{78}$ pertenecen a un período

69 Lamḥa, ed. M. al-Jațīb, 78; trad. Casciaro, 82; sobre ello, Viguera Molins, 2000b: 441-445.

70 Gómez-Moreno, 1940; Pavón Maldonado, 1981-1982; Pavón Maldonado, 1982: 134; Fernández Puertas, 2000: 272.

71 Fernández Puertas, 1992: 218-22; Casamar, 1995: 436-437; García Alfonso, Martínez Enamorado y Morgado Rodríguez, 1999: 225-226; Fernández Puertas, 2000: 271.

72 Lamha, ed. M. al-Jațīb, 126; trad. Casciaro, 141; Viguera Molins, 2000a: 333.

73 Nos inclinamos a que la primera de la hipótesis sea la válida, pues entendemos que lo más probable es que el objeto fuese regalado al príncipe en la festividad que siguió a su circuncisión.

74 Collinet, 2001: 127-128.

75 Fernández Puertas, 2002: 402. De hecho, explica Ferrandis Torres, 1943: 152 que las espadas de jineta se llevaban de dos maneras: en recepciones protocolarias, se suspendía del hombro por dos cintas de seda de colores, con abrazaderas de metales esmaltados, de acuerdo con el testimonio gráfico de la bóveda de la Sala de los Reyes de la Alhambra; en la guerra, se unía al arzón de la silla de montar, como se contempla en la pinturas del Partal.

76 Nafh̆, IV, ed. 'Abbās: 509; este pasaje ha sido traducido y comentado en profundidad por Velázquez Basanta, 2002: 489-496, especialmente 494.

77 Sobre la espada estoque requisada a Boabdil, cfr. Fernández y González, 1875: 389-400; Madrid, 1893: láms LXVI-LXVII; Kühnel, 1924: 124; Ferrandis Torres, 1943: 165-16, fig. 23; Torres Balbás, 1949a: 234, fig. 256 A; Mann, 1961: 20; García Fuentes, 1969: 33; Soler del Campo, 1992a: 282-283, nº 60; 1994b: 321, n 258; 1995a: 147, n 114; Fernández Puertas, 2000: 274-275; 2002: 402-403.

78 Sin embargo, se intuye que en esa captura de armas había más ejemplares que no ingresaron a principios del siglo XIX en el Museo del Ejército, tras la división en dos del patrimonio de Don Juan Bautista Cabrera y Bernuy, marqués de Villaseca. De hecho, alguna de estas espadas se siguen vinculando al último sultán nazarí tras la captura de Lucena. Sobre esta cuestión Soler del Campo, 1994c: 322, nº 259; Fernández Puertas, 2002: 402-403, nota 9. 
anterior al que se le suponía, se podría confirmar indirectamente su pertenencia la tesoro real: la lujosa espada de esmaltes sería del segundo emirato de Muhammad V (763/1362793/1391), mientras que la espada de estoque pertenecería a la época de Yūsuf I (733/1333$755 / 1354)$ o a los primeros años del reinado de su hijo Muhammad V (755/1354-760/1359), según el análisis estilístico relativo a la decoración de ambas piezas ${ }^{79}$. A esta información, habría que añadir otra que puede aclarar el panorama: la hoja de la denominada espada de Boabdil es de cronología claramente posterior a los años finales del siglo $\mathrm{XV}^{80}$.

Por todo ello, a modo de hipótesis bastante plausible, cabe plantearse la posibilidad de que la hoja estudiada, que se fecha con toda claridad por la epigrafía que contiene bajo los emiratos de Yūsuf I y Muhammad V, fuese la compañera de la empuñadura de la espada custodiada en el Museo del Ejército de Madrid. Una vez que falleció Muhammad V bien pudiera suceder que la hoja fuese sustituida por otra en la que no estuviera presente una vinculación tan directa con un sultán como la que exhibía la hoja de al-Ganī bi-llāh: fecha con nombre del sultán predecesor y poema conmemorativo de la conquista de la plaza de Algeciras. A tenor del dato de la pertenencia de la espada al Rey Chico de Granada, que se extrae de la noticia de que una familia sevillana del siglo XVII era propietaria del arma, asunto que a continuación abordaremos, podemos defender ese argumento, con las reservas lógicas que se derivan de las condiciones del descubrimiento de la pieza.

Es el momento para plantearse una pregunta obligada: ¿que hace un niño de tan corta edad como era el por entonces príncipe Muhammad ibn Yūsuf con una espada de tales dimensiones y de tan extraordinaria belleza? Entendemos que es altamente probable que el arma fuese entregada al joven príncipe heredero como regalo en la fiesta de su circuncisión (jitān), celebración en la que el infante suele recibir dádivas diversas, más numerosas y lujosas si pertenece a una clase social elevada, como, evidentemente, es el caso.

Mucha mayor significación tiene la noticia del siglo XVII en la que hemos reparado. Por ella llegamos a la conclusión de que la espada descrita en ese documento es la que estamos estudiando. Recoge Leguina la información de la existencia de una espada de jineta que se custodiaba en Sevilla a fines del siglo XVII en su obra Glosario de voces de la Armería ${ }^{81}$, dato que reproduce prácticamente sin variación Ferrandis ${ }^{82}$. El texto es el siguiente:

«En Sevilla, a fines del siglo XVII, se guardaba una espada de aquel Rey ${ }^{83}$, según se deduce del siguiente curioso documento:

«Noticia de la espada del Rey Chico de Granada, que se conserva en poder de la antiquísima y nobilísima familia del Señor D. Bartolomé Pérez Navarro, veinte y cuatro de la M. N. y M. L. Ciudad de Sevilla.

Contiene lo siguiente desde el puño hasta la punta por un lado:

'El nombre de la espada es el Fibril, que significa el Desagraviador'84

'En el nombre de Dios poderoso y misericordioso. Dios sólo es Dios. Todo por Él está dispuesto.'

'Dios sólo es justo y sabe todas las cosas como executar y perdonar: en el año de 47.

'Después de la plena expiración de los setecientos años del Hégira ${ }^{85}$ : Muley el Sultán, hijo de Muley el Sultán, el conquistador y moderador. (Abdellah Mehames Alenzar).

'A quien

'concedió Dios buenos días y su ayuda.

Te mato en el estrago:

Dios perdone tus pecados que te han condenado.'

79 Fernández Puertas, 2002: 402-403.

80 Soler del Campo, 1992d: 288.

81 Leguina, 1912: 417-418.

82 Ferrandis Torres, 1943: 163-164

83 Se está refiriendo a Boabdil.

84 Parece estar haciendo alusión al cuño que contiene bien el nombre del orfebre Fat.,h, bien alguna de las palabras derivadas de las raíces f.l.y/f.l.h /f.l.j.

85 Obsérvese que en la traducción se ha respetado íntegramente la forma árabe de la fechación: 'àm saba'a waarba'ūn ba'd saba' mi'a min al-hiŷra. 
Desde la punta hasta el puño al otro lado, hay lo siguiente como hablando con la espada: Desempéñate y llenad la mano con quien te llegare. Paz sea contigo con riquezas y abundancias, mas ... 'No a los infieles. Boraldos [sic] tus procedimientos sean con dominio (o tres progresos). 'Afilate para matar y sugétalos a tu gobierno.'

'Tu puerta es nuestras puertas, en sus brechas harás hazañas.

'Yo corto con filo agudo y sano las heridas.

'Mi padre fue un conquistador de los cristianos...'

Traducción de D. Roberto Godeschalque en 1693.»

Poco comentario tiene esta traducción si se compara con la que ofrecemos. Todo es coincidente con los pasajes textuales que contiene el arma en cuestión. Si bien, como es lógico, la traducción del árabe realizada por el tal Roberto Godeschalque es hija de su época, los indicios se dirigen a señalar que la pieza que se guardaba en aquella casa sevillana se corresponde con la espada de Muhammad V. Especialmente, la inscripción A, que contiene fragmentos coránicos y fórmulas repetitivas de la epigrafía árabe de todo tiempo y lugar, es plenamente concordante con la traducción de Godeschalque en estructura, contenido y fechación $^{86}$. La diferencia con la traducción realizada para el pasaje B salta a la vista, lo que resulta lógico al tratarse de un poema desconocido por entonces, por lo que la versión resultaba ser una labor bastante más compleja para lo que se requería un conocimiento del árabe que el traductor seguramente no poseería. Y sin embargo, hay asimismo rasgos coincidentes con el poema, por más que en la traducción aparezca desfigurado totalmente.

Más tarde, es muy probable que el ejemplar saliera de España a raíz de la invasión napoleónica o de alguna de las desamortizaciones del siglo XIX, aunque, por ahora, no tengamos noticias al respecto. Recordemos, a título de ejemplo, como a principios del siglo XVIII, el famoso arqueólogo español Antonio Conde realiza una descripción minuciosa de una espada de la jineta granadina en su posesión que le fue robada por un soldado francés durante la invasión napoleónica ${ }^{87}$.

VIRGILIO MARTÍNEZ ENAMORADO

Doctor en Historia Medieval

virmar@auna.com

\section{BIBLIOGRAFÍA}

Fuentes medievales

Crónica de Juan II de Castilla, ed. De J. de M. Carriazo y Arroquia, Real Academia de la Historia, Madrid, 1982.

IBN HUDAYL, Gala de caballeros, blasón de paladines, trad. castellana con introducción de M. J. Viguera Molins de la obra Kitāb hilyat al-fursān, Madrid, 1977.

IBN JALDŪN, al-'Ibar: Kitāb al-'Ibar, ed. J. Šihāda y revisada por S. Zakkār, Beirut, 1981; trad. francesa de M. G. de Slane, Histoire des Berbères et des dynasties musulmanes de l'Afrique septentrionale, 4 vols., Argel, 1852-1856; reimpresión facsímil, París, 1969 y 1978.

86 Basmala= En el nombre de Dios poderoso y misericordioso; primera parte del enunciado de la šahāda $($ tahlīl $)=$ Dios sólo es dios; expresión «Todo el poder es de Dios»= Dios sólo es justo; expresión «Dios es el mejor protector y el más misericordioso de los misericordiosos» $=$ y sabe todas las cosas como executar y perdonar; fechación y filiación de la pieza= en el año de 47 despuésde la plena expiración de los setecientos años de la Hégira; Muley el Sultán, hijo de Muley el Sultán, el conquistador y moderador (Abdallah Mehames Alenzar); Corán, 48, 1-2= A quien concedió Dios buenos días y su ayuda. Te mato en el estrago: Dios perdone tus pecados que te han condenado.

87 González, 1994: 161. 
IBN JALDŪN, al-Ta 'rīf: al-Ta 'rīf bi-Ibn Jaldūn wa-riḥlatu-hu garban wa-šarqan, Beirut, 1979.

IBN AL-JAṬ̄̄B, Dīwān, ed.Muhammad al-Šarīf al-Qāhir, Argel, 1973.

IBN AL-JATīB, Ihậta: al-Ihātạ fì ajbār Garnāṭa, ed. Muḥammad 'Abd Allāh 'Inān, 4 vols., El Cairo, 1973-1977 (I, 1973; II, 1974; III, 1975; IV, 1977).

IBN AL-JAȚ̄̄B, Lamha: al-Lamha al-badriyya fi l-dawla al-nașriyya, ed. Muḥibb al-Dīn al-Jațîb, El Cairo, 1954; $3^{\text {a }}$ ed. Muhibb al-Dīn al-Jațīb, Beirut, 1978; Historia de los Reyes de la Alhambra. El resplandor de la luna llena (al-Lamha al-badriyya), estudio preliminar por E. Molina López, trad. e introducción de J. M. Casciaro Ramírez, Granada, 1998.

IBN AL-JAṬ̄B, Mi ‘yār al-ijtiyār fi dikr al-ma ‘āhid wa-l-diyār, ed. con estudio crítico y traducción al castellano de M. K. Śabāna, Rabat, 1977.

IBN AL-JAṬ̄̄B, Nufāda III: Nufādatat al-ŷirāb fì 'ulālat al-igtirāâ, parte tercera, ed. E introducción crítica de S. Fāgiya, Casablanca, 1989.

IBN AL-JAṬ̄B, Rayhānat al-kuttab: Rayḥ̄nat al-kuttab wa-nuŷa'at al-muntāb, ed. Muhammad 'Abd Allāh 'Inān, El Cairo, 1980, 2 vols.; ed. y trad. parcial de M. Gaspar Remiro, «Correspondencia diplomática entre Granada y Fez (s. XIV). Extractos de la 'Reihanat alcuttab' de Lisannendin Abenaljatib», Revista del Centro de Estudios Históricos de Granada y su Reino, I-VI (1911-1916).

IBN MARZūQ, El Musnad: hechos memorables de Abū l-Hasan, sultán de los benimerines, estudio, traducción, anotación e índices anotados de M. J. Viguera Molins, Instituto Hispan-Árabe de Cultura, Madrid, 1977.

IBN ZAMraK, Dīwān Ibn Zamrak al-Andalusī, Muhammad ibn Yūsuf al-Sarīhị, bi-'timad 'alà majțūt farìd 'unwānu-hu «Al-baqiya wa-l-mudrak min ši'r Ibn Zamrak», ed. M. T. al-Nayfar, Beirut, 1997.

Al-MaQQARĪ, Nafh: Nafh al-țīb min guṣn al-Andalus wa l-rațīb, ed. Iḥsān 'Abbās, 8 vols., Beirut, 1968.

AL-NĀṣIRĪ, Kitāb al-istiqșà: Kitāb al-istiqṣà li-ajbār duwal al-Magrib al-aqșà (Histoire du Maroc), trad. I. Hamet, Archives Marocaines, 33, París.

Yusuf III, Dīwān Yūsuf III, ed. 'Abd Allāh Kannūn, Tetuán, 1958; 2ª ed. El Cairo, 1965.

Obras generales

'ABBĀDĪ, M. (1975): El Reino de Granada en la época de Muhammad V, Madrid.

ABboud HagGaR, S. (1998): «La defensa del litoral a través de al-Ihạața de Ibn al-Hațīb», I Congreso Internacional Fortificaciones en al-Andalus (Algeciras, 1996), Algeciras, 157-167.

Almagro CÁRdenAS, A. (1879): Estudio sobre las inscripciones árabes de Granada, con un apéndice sobre la Madraza o Universidad Árabe, Granada.

Aouni, L. M. (1991): Étude des inscriptions mérinides a Fès, tesis doctoral microfilmada, Université Aix-Marseille.

ARIÉ, R. (1990): L’Espagne musulmane au temps des Nas,.rides (1232-1492), París, 1973; reimpresión y puesta al día, París.

Arjona Castro, A. (1985): «Castillos de Córdoba: Carcabuey y Tiñosa», Boletín de la Real Academia de Córdoba, 109, 89-104.

BARCEló TORRES, C. (1990): «Estructura textual de los epitafios andalusíes (siglos IX-XIII), Homenaje a Manuel Ocaña Jiménez, Córdoba, 41-54.

BLACHERE, R. (1936): «Le Vizir et poète Ibn Zamrak et son oeuvre», Annuaires de l'Institut des Études Orientales d'Alger, 291-312.

BLAIR, S. S. (1998): Islamic Inscriptions, Edimburgo.

CABANElas RodríGuez, D. (1976): «Las inscripciones de la Alhambra según el morisco granadino Alonso del Castillo», Miscelánea de Estudios Árabes y Hebraicos, XXV (1976), 7-32. 
Cabanelas Rodríguez, D. (1991): El morisco granadino Alonso del Castillo, Patronato de la Alhambra y el Generalife, Granada.

CASAmar, M. (1995): «Silla de caderas o jamuga», Arte islámico en Granada. Propuesta para un Museo de la Alhambra, catálogo de la exposición, Granada, 436-437, nº 188.

Collinet, A. (2001): «Le métal ayyoubide», en L'Orient de Saladin. L'art des Ayyoubides, Exposición del Instituto del Mundo Árabe (París, 2001-2002), París, 127-130.

Corriente, F. (1990): «Catorce cejeles de Ibn Zamrak y uno de Ibn Alxațīb», Anaquel de Estudios Árabes, 1, 1-33.

EGUARAs IBÁÑEZ, J. (1944): Las principales inscripciones árabes del Museo Arqueológico de Granada», Memoria de los Museos Arqueológicos Provinciales, 5, 103-118.

FERnÁNDEZ y GonZÁLEZ, F. (1875) : «Espadas hispano-árabes», Museo Español de Antigüedades, vol. 5, 389-400.

FERNÁNDEZ PUERTAS, A. (1977): «En torno a la cronología de la torre de Abū l-Haŷŷâŷ», XXIII Congreso Internacional de Historia del Arte: España entre el Mediterráneo y el Atlántico (Granada, 1973), vol. II, Granada, 76-88.

Fernández Puertas, A. (1980): La fachada del Palacio de Comares. I. Situación, Función y Génesis, Patronato de la Alhambra, Granada.

FERnÁNDEZ Puertas, A. (1992): «139. España», Arte y Cultura en torno a 1492, Exposición Internacional de 1992, Sevilla, 218-220.

FERnÁndez Puertas, A. (2000): «El Arte» en M. J. Viguera Molins (coord.), vol. VIII-4 de la Historia de España de Menéndez Pidal dirigida por J. M. Jover Zamora: El Reino nazari de Granada (1232-1492). Sociedad, vida y cultura, Madrid, 191-284.

FERnÁNDEZ Puertas, A. (2002): «Vestimenta de Abū 'Abd Allāh Muhammad, Boabdil: Rīhiyyya, Juff, Mallūța, 'Imāma», en C. del Moral (ed.), En el epílogo del Islam andalusí: la Granada del siglo $X V$, Universidad de Granada, Granada, 399-477.

FERrANDis TORRES, J. (1943): «Espadas granadinas de la jineta», Archivo Español de Arte, 57 , 142-166.

García Alfonso, E., Martínez Enamorado, V. y Morgado Rodríguez, A. (1999): Museos Arqueológicos de Andalucía (II). Almería, Granada, Jaén y Málaga, Granada.

GARCía FuENTES, J. Ma (1969): «Las armas hispanomusulmanas al final de la Reconquista», Chronica Nova, 3, 7-38.

GArcía GómEZ, E. (1975): Ibn Zamrak, el poeta de la Alhambra, Patronato de la Alhambra, Granada.

GARcía Gómez, E. (1985): Poemas árabes en los muros y fuentes de la Alhambra editados y traducidos en verso, con introducción y notas por E. García Gómez, Instituto Egipcio de Estudios Islámicos, Madrid.

GARCía GóMEZ, E. (1988): Foco de antigua luz sobre la Alhambra desde un texto de Ibn al-Jațīb en 1362, Instituto Egipcio de Estudios Islámicos, Madrid.

GASPAR Remiro, M. (1911): «Inscripciones de la Alhambra. Errata corrigenda», Revista del Centro de Estudios Históricos de Granada y su Reino, I, 39-41.

GASPAR REMIRO, M. (1914):: «Cartas del sultán de Granada Mohamed V, hijo de Abulhachach Yúsuf al jefe de Meca y a los sultanes de África, notificándoles importantes conquistas y terribles algaras que ha realizado sobre las plazas y tierras fronterizas de los cristianos de Castilla», doc. XII de la serie «Correspondencia diplomática entre Granada y Fez (s. XIV). Extractos de la 'Reihanat alcuttab' de Lisannendin Abenaljatib», Revista del Centro de Estudios Históricos de Granada y su Reino, 4, 294-302.

GómeZ-Moreno GonZÁLEZ, M. (1892): Guía de Granada, 2 vols., Granada (reed. 1982)

GómEZ-MorEno MartínEZ, M. (1940): «El bastón del cardenal Cisneros», Al-Andalus, V, 192-195.

GonZALEZ, V. (1994): Émaux d'al-Andalus et du Maghreb, Aix-en-Provence. 
Hernández NúÑEZ, J. C. (1999): «Espada de San Fernando», Metropolis Totius Hispaniae. 750 Aniversario de la Incorporación de Sevilla a la Corona Castellana, Sevilla, 234-235.

KÜHNEL, E. (1924): Maurische Kunst, Die Kunst des Ostens, 9, Berlín.

LAFUENTE AlCÁNTARA, E. (2000): Inscripciones árabes de Granada, precedidas de una reseña histórica y de la genealogía detallada de los reyes Alhamares, edición facsímil de la de 1859 con estudio preliminar de M. J. Rubiera Mata, Granada.

LEGUINA, E. de (1912): Glosario de voces de Armería. Apuntes reunidos por D. Enrique de Leguina, barón de la Vega de Hoz, Madrid.

LEVI-PROVENÇAL, E. (1931): Inscriptions arabes d'Espagne, Leyden-París.

MADRID (1893): Las Joyas de la Exposición Histórico-Europea de Madrid. 1892. Catálogo de la exposición, 2 vols., Madrid.

MAKKĪ, M. A. (1984): «Dirāsa wa-taqdīm wa-tahqīì», estudio, prólogo y edición de la obra de Ibn Simāk, al-Zaharāt al-mantūura fì nakt al-ajbār al-màtūura, Instituto Egipcio de Estudios Islámicos, Madrid.

ManN, J. (1933): «Notes of the Armour worn in Spain from the tenth to the fifteenth century», Archaeologia, 83, 285-305.

MARTÍNEZ ENAMORADO, V. (1998a): Epigrafia y poder. Inscripciones árabes de la Madrasa al$\hat{Y}$ adìda de Ceuta, Ceuta.

MARTÍNEZ ENAMORADO, V. (2005): «Más sobre epigrafía nazarí y meriní a partir de la lápida de Cañete de las Torres conservada en el Museo Arqueológico de Córdoba», Anales de Arqueología Cordobesa, 15.

Medina Gómez, A. (1992): Monedas hispano-musulmanas. Manual de lectura y clasificación, Instituto Provincial de Investigaciones y Estudios Toledanos, Serie 3: Estudios, Catálogos y Repertorios, 16, Madrid.

MOLINA LóPEZ, E. (2001): Ibn al-Jatib, Granada.

Morales Delgado, A. (1999): «Ibn Zamrak editado. Según al manuscrito al-Baqiya wa-lmudrak min ši ‘r Ibn Zamrak», en C. Castillo Castillo, I. Cortés Peña y J. P. Monferrer Sala (eds.), Estudios Árabes dedicados a D. Luis Seco de Lucena (en el XXV Aniversario de su muerte), Universidad de Granada, Granada, 139-145.

Orihuela Uzal, A. (1996): Casas y Palacios nazaries. Siglos XIII-XV, El Legado Andalusí, Granada.

PAVÓN MALdonAdo, B. (1970): «Escudos y Reyes en el Cuarto de los Leones de la Alhambra», Al-Andalus, XXXV, 179-197.

PAVÓN MALDONADO, B (1972): «Notas sobre el escudo de la Orden de la Banda en los palacios de Don Pedro y de Muhammad V», Al-Andalus, XXXVII, 229-232.

PAVÓN MALDONADO, B (1981-1982): «Notas sobre Arte y Arqueología Hispano-musulmana en Andalucía. IV. En torno al 'bastón' del cardenal Cisneros», Andalucía Islámica. Textos y Estudios, IIIII, 214-219.

Pavón Maldonado, B (1982): Alcalá de Henares medieval: arte islámico y mudéjar, Madrid.

Pavón Maldonado, B (1991): El Cuarto Real de Santo Domingo de Granada, Granada

PUERTA Vílchez, J. M. (1990): Los códigos de utopía de la Alhambra de Granada, Diputación Provincial de Granada.

Puerta Vílchez, J. M (2001): «El vocabulario estético de los poemas de la Alhambra», en J. A. González Alcantud y A. Malpica Cuello (eds.), Pensar la Alhambra, Granada, 69-88.

Ríos Villalta, R. A de los (1883): Museo Arqueológico Nacional. Memoria acerca de algunas inscripciones arábigas de España y Portugal, presentada al Excmo. Jefe del referido establecimiento, Madrid.

Robles Fernández, A. y NAVArro SAntA-Cruz, E. (2000): Tesoro áureo de Murcia. Circulación monetaria en la época de los Reyes Católicos, catálogo de exposición (Murcia, 2000), Murcia. 
RUBiera Mata, Ma J. (1994): Ibn al-Ŷayyāb. El otro poeta de la Alhambra, Patronato de la Alhambra y el Generalife, Granada.

RUBiERA MATA, Ma J. (1995): «Los textos epigráficos de los palacios nazaríes (algo más que una escritura)», Arte islámico en Granada. Propuesta para un Museo de la Alhambra, Granada, 96-105.

RUBIERA MATA, M J J. (2000): «Estudio preliminar», en E. Lafuente Alcántara, Inscripciones árabes de Granada, precedidas de una reseña histórica y de la genealogía detallada de los reyes Alhamares, edición facsímil de la de 1859, Granada.

Salameh, I. M. O. (2000): «Bāb al-Šarī‘a», 3. ${ }^{\circ}$ Congresso de Arqueologia Peninsular (Vila Real, 1999). Vol. 7. Arqueologia da Idade Média da Península Ibérica, Oporto, 319-346.

Soler Del CAMPo, A. (1992a): «Espada y vaina», en J. D. Dodds (ed.), Al-Andalus. Las Artes Islámicas en España, catálogo de la exposición de la Alhambra, Metropolitan Museum de Nueva York, Madrid, 282-283, $\mathrm{n}^{\circ} 60$.

SOlER DEl CAMPO, A. (1992b): «Espada jineta y vaina», en J. D. Dodds (ed.), Al-Andalus. Las Artes Islámicas en España, catálogo de la exposición de la Alhambra, Metropolitan Museum de Nueva York, Madrid, 284-286, $\mathrm{n}^{\circ} 61$.

SOlER DEL CAMPO, A. (1992c): «Espada jineta y vaina», en J. D. Dodds (ed.), Al-Andalus. Las Artes Islámicas en España, catálogo de la exposición de la Alhambra, Metropolitan Museum de Nueva York, Madrid, 286-287, $\mathrm{n}^{\circ} 62$

SOlER DEl CAMPO, A. (1992d): «Espada jineta, vaina y fragmento de tahalí», en J. D. Dodds (ed.), Al-Andalus. Las Artes Islámicas en España, catálogo de la exposición de la Alhambra, Metropolitan Museum de Nueva York, Madrid, 288-290, nº 63.

SOlER Del CAMPO, A. (1994a): «Espada jineta», La paz y la guerra en la época del Tratado de Tordesillas, Sociedad V Centenario del Tratado de Tordesillas, Consejería de Cultura y Turismo de la Junta de Castilla y León, Madrid, 320, nº 257.

SOlER DEL CAMPO, A. (1994b): «Daga de orejas con vaina. Cinturón con escarcela. Estuche», La paz y la guerra en la época del Tratado de Tordesillas, Sociedad V Centenario del Tratado de Tordesillas, Consejería de Cultura y Turismo de la Junta de Castilla y León, Madrid, 321, nº 258.

SOLER DEL CAMPO, A. (1994c): «Espada», La paz y la guerra en la época del Tratado de Tordesillas, Sociedad V Centenario del Tratado de Tordesillas, Consejería de Cultura y Turismo de la Junta de Castilla y León, Madrid, 322, nº 259.

SOLER DEL CAMPO, A. (1995a): «Espada», en El zoco. Vida económica y artes radicionales en alAndalus y Marruecos, catálogo de la exposición (Jaén, 1995), Madrid, 147, nº 114.

SOLER DEL CAMPO, A. (1995b): «Espada jineta», en El zoco. Vida económica y artes radicionales en al-Andalus y Marruecos, catálogo de la exposición (Jaén, 1995), Madrid, 147, nº 115.

SOler Del CAMPO, A. (1995c): «Espada», El zoco. Vida económica y artes radicionales en alAndalus y Marruecos, catálogo de la exposición (Jaén, 1995), Madrid, 146, $\mathrm{n}^{\circ} 113$.

TORREMOCHA SiLVA, A. (1994): Algeciras entre la Cristiandad y el Islam. Estudios sobre el cerco y conquista de Algeciras por el rey Alfonso XI de Castilla, así como de la ciudad y sus términos hasta el final de la Edad Media, Instituto de Estudios Campogibraltareños, Algeciras.

Torremocha Silva, A. y SÁez RodríGuez, A. J. (2001): «Algeciras medieval», en M. Ocaña (coord.), Historia de Algeciras, 3 vols., tomo I: De los orígenes a la época medieval, Diputación de Cádiz, Cádiz, 173-318.

TORremocha Silva, A. et alii, 1999: Al-Binya, la ciudad palatina meriní de Algeciras, Fundación Municipal de Cultura, Algeciras.

Torres BALBÁs, L. (1944): El Maristán de Granada», Al-Andalus, 9, 481-498.

VÁzQuez Ruiz, J. (1999): «La 'Puerta de la Justicia' de la Alhambra», en C. Castillo Castillo, I. Cortés Peña y J. P. Monferrer Sala (eds.), Estudios Árabes dedicados a D. Luis Seco de Lucena (en el XXV Aniversario de su muerte), Universidad de Granada, Granada, 1999, 247-255. 
Vega Martín, M. Y PeÑa Martín, S. (2002-2003): «Alternancias epigráficas en las monedas almorávides», Al-Andalus-Magreb, 10, 293-314.

Vega Martín, S., Peña Martín, S. y Feria García, M. C. (2002): El mensaje de las monedas almohades. Numismática, traducción y pensamiento islámico, Cuenca.

VELÁZQUEZ BASANTA, F. N. (2002): «La relación histórica sobre las postrimerías del Reino de Granada, según Ahmad al-Maqqarī (s. XVII)», C. del Moral (ed.), En el epílogo del Islam andalusí: la Granada del siglo XV, Universidad de Granada, Granada, 481-554.

VidAl CAstro, F. (2000): «Historia Política», en Ma J. Viguera Molins (coordinadora), vol. VIII/3 de Historia de España de Menéndez Pidal dirigida por J. M. Jover Zamora: El Reino nazarí de Granada (1232-1492). Política. Instituciones. Espacio y Economía, Madrid, 47-248.

Viguera Molins, M ${ }^{\mathrm{a}}$ J. (2000A): «El soberano, visires y secretarios», en M. J. Viguera Molins (coordinadora), vol. VIII/3 de Historia de España de Menéndez Pidal dirigida por J. M. Jover Zamora: El Reino nazarí de Granada (1232-1492). Política. Instituciones. Espacio y Economía, Madrid, 317-363.

Viguera Molins, M ${ }^{\mathrm{a}}$ J. (2000b): «El ejército», en M. J. Viguera Molins (coordinadora), vol. VIII/3 de Historia de España de Menéndez Pidal dirigida por J. M. Jover Zamora: El Reino nazarí de Granada (1232-1492). Política. Instituciones. Espacio y Economía, Madrid, 429-475.

VÍLCHEZ Vílchez, C. (1991): El Generalife, Granada.

WARD, R. (1993): Islamic Metalwork, British Museum, Londres.

ŶARRĀR, Ș. (1999): Dīwān al-Hamrā', Ammán.

ZAKĪ, A. R. (1957): «Al-nuqūš al-zujrufiya wa-l-kitābāt 'alà suyūf al-islāmiya», Revista del Instituto Egipcio de Estudios Islámicos, 5, 227-239. 